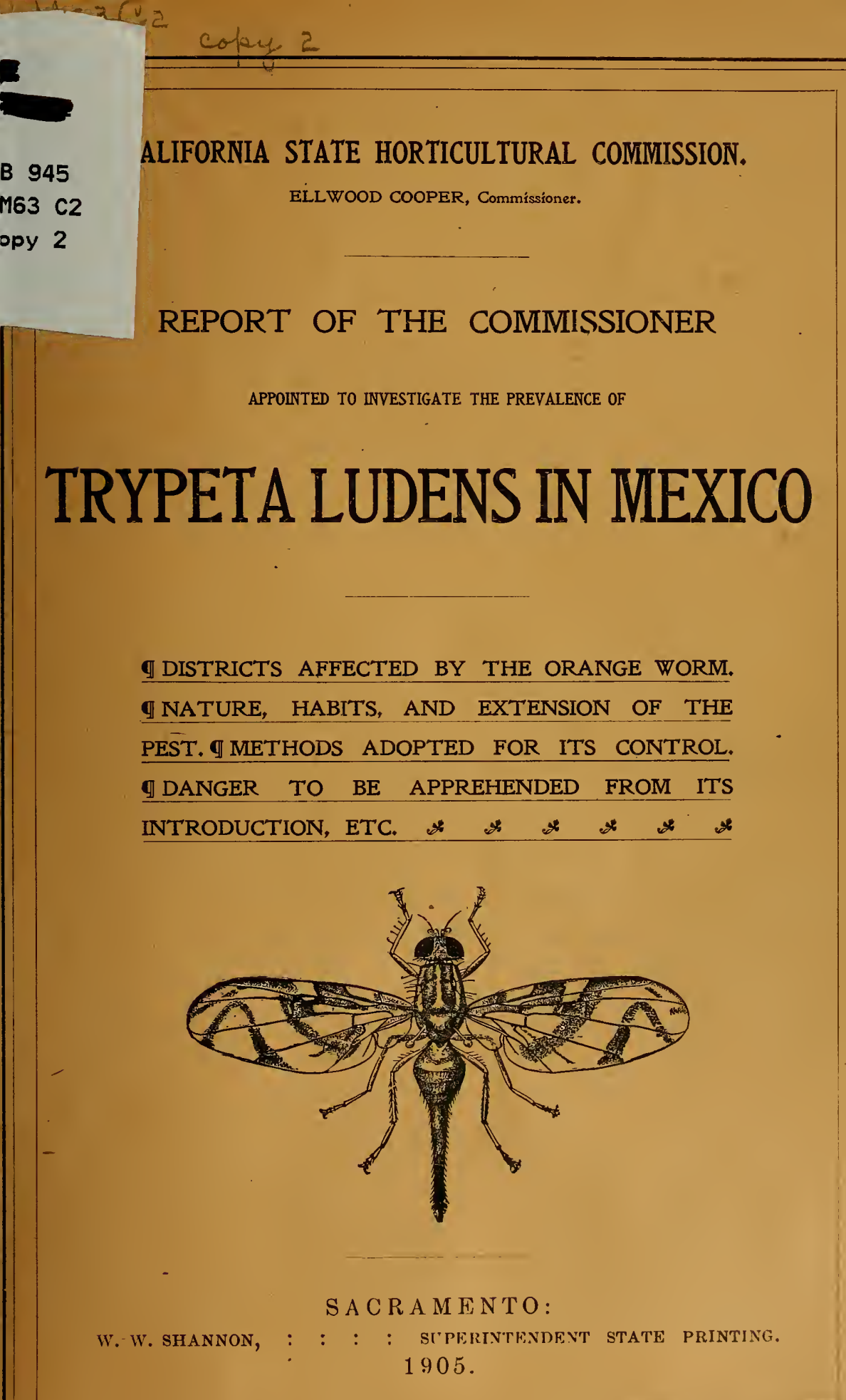





\section{MAP OF MFXICO,}

Showing areas infested by the Orange Worm (Trypeta ludens) and the annual orange product of the dif

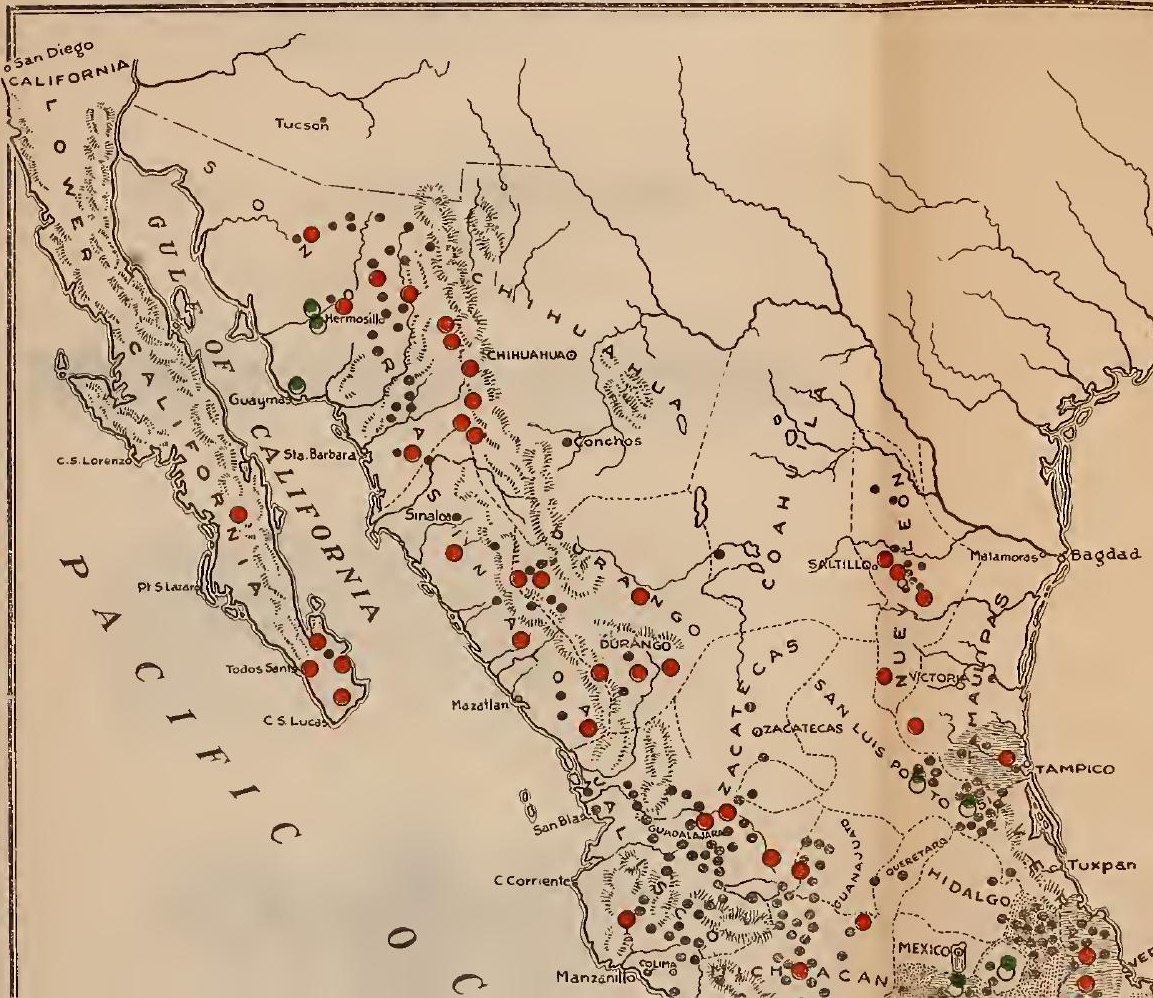




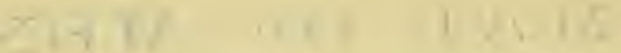

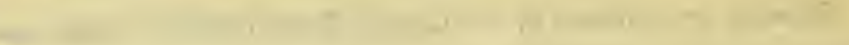

10
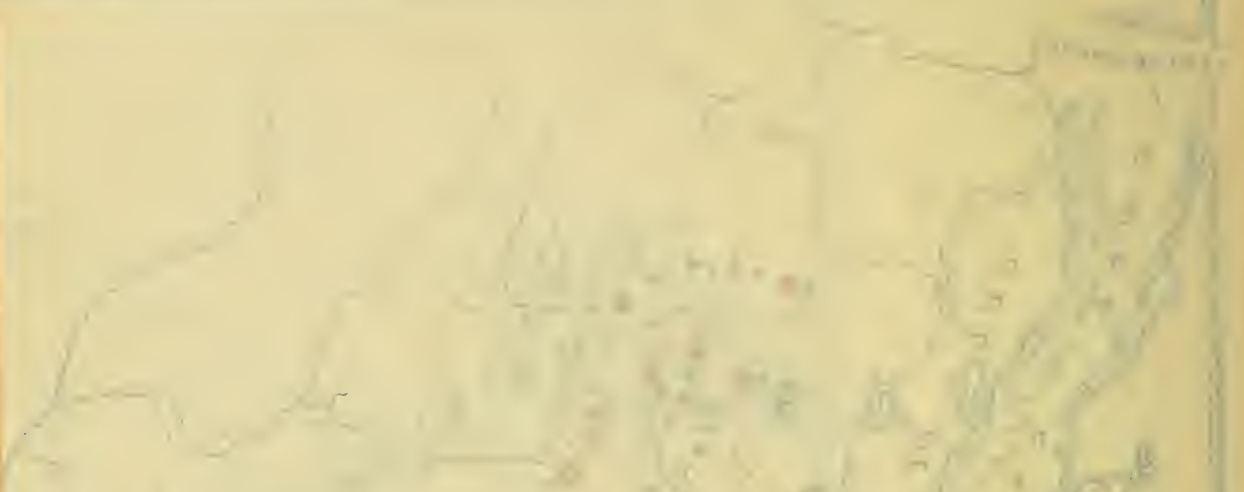

$\frac{1}{4}+\ldots$

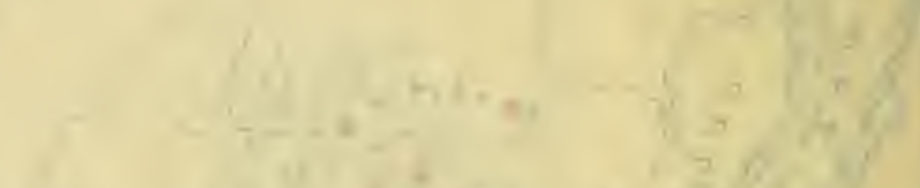

n

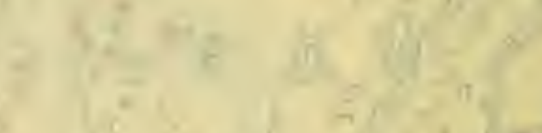

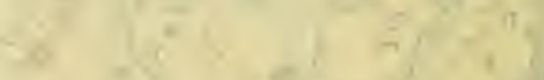

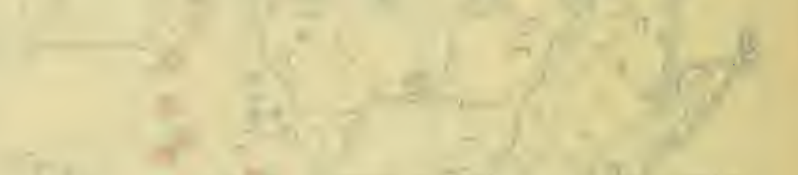

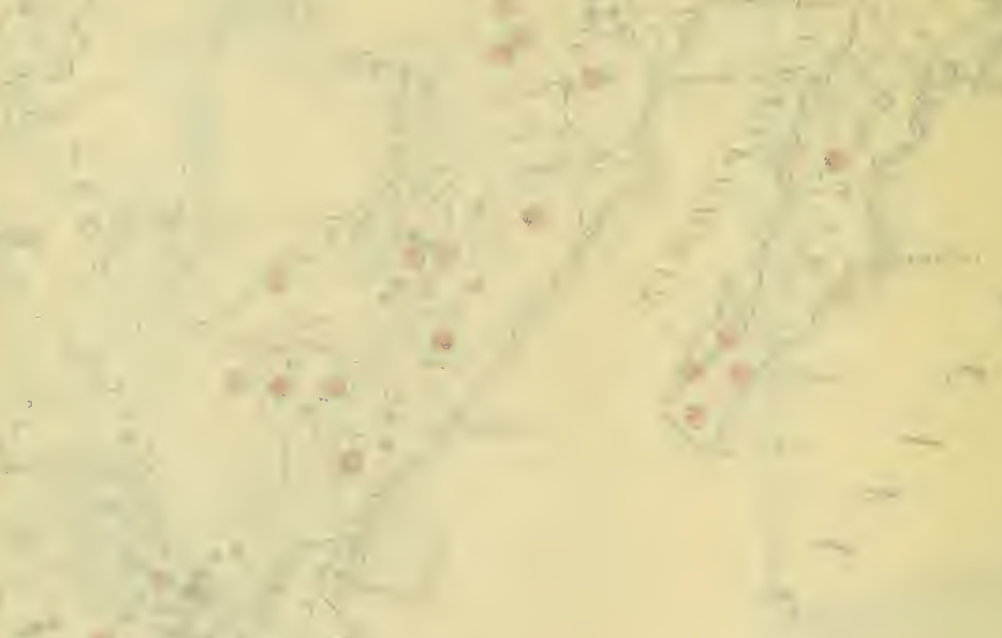

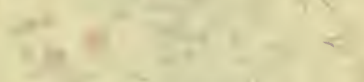

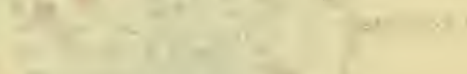

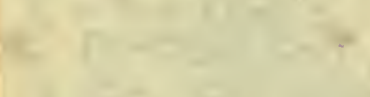

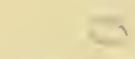

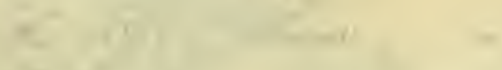

12

OOTKM M 


\section{CALIFORNIA STATE HORTICULTURAL COMIIISSION.}

ELLWOOD COOPER, Commissioner.

\section{REPORT OF THE COMIMISSIONER}

APPOINTED TO INVESTIGATE THE PREVALENCE OF

\section{TRYPETA LUDENS IN MEXICO}

I DISTRICTS AFFECTED BY THE ORANGE WORM. I NATURE, HABITS, AND EXTENSION OF THE PEST. METHODS ADOPTED FOR ITS CONTROL. IDANGER TO BE APPREHENDED FROM ITS INTRODUCTION, ETC. $* * * * *$

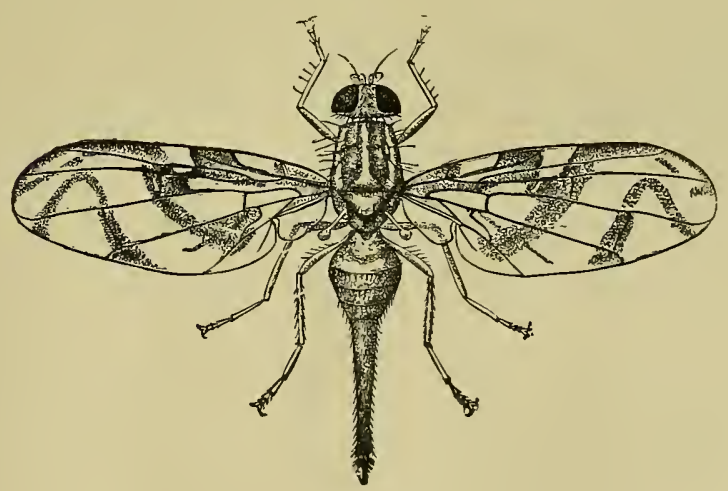

SACRAMENTO:

W. W. ShaNNON, : : : : SUPERINTENDENT STATE PRINTING. 1905 . 


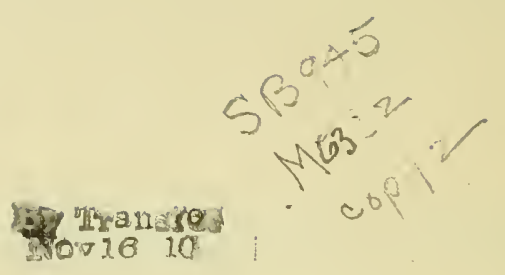

CALIFORNIA STATE COMMISSION OF HORTICULTURE.

ELLWOOD COOPER Commissioner Santa Barbara.

JOHN ISAAC Secretary San Francisco.

ED. M. EHRHORN Deputy Mountain View.

E. K. CARNES Assistant Deputy Riverside.

O. E. BREMNER Second Assistant Santa Rosa. GERTRUDE BIRD Stenographer Sacramento.

OFFICE:

Room 41, State Capitol, Sacramento.

Branch Office, Room 11, Ferry Building, San Francisco. 
OFFICE OF THE

State Horticultural Commissioner.

Sacramento, Cal., June 25, 1905.

To His Excellency, George C. Pardee, Governor of California:

SIR: In accordance with the instructions issued by you, ordering that an investigation be made into the prevalence and spread of the orange maggot in Mexico, and the danger to be apprehended from its introduction into California, I have had such investigation made, and have the honor to present you herewith the report of the same.

Respectfully submitted.

ELLWOOD COOPER,

Commissioner. 



\section{INTRODUCTION.}

For many years past it has been known that there existed in Mexico a serious pest of the orange, which, in its larval form, worked in the pulp of the fruit, reducing it to a rotten mass unfit for use. As the Republic of Mexico is very near to our own State, our orange-growers were naturally alarmed at the possibility of the pest crossing the border and becoming established in the orchards of this State. This alarm was increased when, in November, 1899, Mr. Alexander Craw, the Horticultural Quarantine Officer of the State Board of Horticulture, discovered the pest in a shipment of Mexican oranges from Acapulco, and this resulted in the placing of an embargo on all oranges coming into this State from Mexico. The result of this embargo was a voluminous correspondence between the Department of Fomento, in Mexico, and the Department of State at Washington, D. C., which was referred to Governor Pardee. This correspondence, the greater part of which was published in the First Biennial Report of the Commissioner of Horticulture, pages 43 et seq., led to a request from the Mexican Government, through the Department of Fomento, that an agent of the California Commission of Horticulture be dispatched to make a thorough investigation of the prevalence of the orange pest in Mexico, to inspect the work which has been done looking to its eradicátion, and to make a report as to the exact condition of matters in the affected districts, in order that unnecessary alarm, which our Mexican neighbors believed existed among our growers, might be removed. Complying with this request, an agent of the Commission of Horticulture, by the advice and with the consent of Governor Pardee, was appointed by Ellwood Cooper, Commissioner of Horticulture, with instructions that he report to Prof. A. L. Herrera, who was appointed to represent the Mexican Government in the investigation, at the City of Mexico, on March 15, 1905.

In accordance with these instructions the work of investigation was commenced on the date above mentioned, Professor Herrera representing the Department of Fomento (which branch of the Mexican Government has charge of the agricultural and horticultural interests of the Republic), and Mr. John Isaac representing the State of California, through the Commission of Horticulture. The result of these investigations is given in the following report.

Inasmuch as comparatively little is known, by the greater part of our orange-growers, in regard to this pest, and in view of the fact that a very 
great fear exists as to its introduction and spread in our State, this report is devoted to a very full description of this insect, as well as to an account of the regions infested and the damage wrought by it.

In this connection we wish to acknowledge the assistance rendered us in this work by Prof. A. L. Herrera and the Department of Fomento which he represents. For many years this department of the Mexican Government has made a thorough study of this pest and resorted to every means possible to check its ravages, and in the following pages we have availed ourselves of the great fund of information accumulated by Professor Herrera. We are also indebted to his department for the use of several of our illustrations. 


\title{
REPORT
}

\author{
ON THE
}

\section{MEXICAN ORANGE WORM (TRYPETA LUDENS) IN MEXICO.}

\section{BY JOHN ISAAC.}

To Hon. Ellwood Cooper, State Commissioner of Horticulture, Sacramento, California:

SIR: In accordance with your instructions to visit the Republic of Mexico and investigate the extent of territory affected by the Mexican orange worm, the amount of damage done, and the danger of the introduction of this pest into California, as conveyed in your letter of March 2, 1905, given herewith, I have the honor to hand you my report.

\section{LETTER OF INSTRUCTIONS.}

\section{To Mr. John IsAac, Sacramento, Cal.:}

Sacramento, Cal., March 2, 1905.

Sin: You are hereby appointed and instructed to proceed to the City of Mexico, and, on your arrival there, to report to the Honorable Secretary of the Foreign Office, in order that your mission while traveling in that country may be understood.

An agreement, consummated through the Hon. John Hay, Secretary of State, communicated to His Excellency, George C. Pardee, Governor of the State of California, dated at Washington, January 21, 1905, has been referred by His Excellency, with all communications relating thereto, to this office for consideration and action.

You are familiar with this correspondence and the object of your mission, which is to investigate the Morelos orange maggot (Trypeta ludens) in the different provinces of Mexico, and to ascertain the extent of the injury caused by this pest in the orange and sweet-lime orchards.

You are aware of the vast territory devoted to orange-growing in California, and the danger of the introduction of said pest into our State. In such an event the loss might amount to millions of dollars.

You will meet Prof. Alfonso L. Herrera, who is the head of the Agricultural Commission on Parasites, and who has been detailed to accompany you on this mission.

Your experience in the Quarantine Department of the Horticultural Commission in San Francisco, with your knowledge of the propagation of parasitic insects, and a general knowledge of entomology, eminently fits you for such a mission.

In your examination of the orange and lime plantations, in the different districts where the pest exists, you will be careful to observe whether the damage is caused solely by one species of fruit fly, or by several species.

You will collect, and send here in alcohol, specimens of the flies, larva and pupa, 
giving extent of damage, with such particulars of the natural history as may be important to this office.

You are aware that the season is short for such an investigation, hence the necessity of expediting the work.

(Signed:) ELLWOOD COOPER,

State Horticultural Commissioner.

(Signed:) GEORGE C. PARDEE,

Governor of the State of California.

(Signed:) CHARLES F. CURRY,

Secretary of State.

In accordance with these instructions I met with the representative of the Mexican Gorernment, Prof. A. L. Herrera, on March 15th, and the following day in his company called upon General de Cosio, the then Chief of the Department of Fomento, to whom I presented my credentials. General de Cosio assured me that every possible facility which the Mexican Government could afford would be given in the prosecution of our work, and Professor Herrera was instructed to place all facilities of the Commission of Parasitologia, of which he is the chief, at our service.

In a subsequent meeting it was decided to commence operations in the State of Morelos, it being the worst infested section of the Republic, and to continue our operations from that point as a center. In the course of our investigations we visited all the more important orange sections of Mexico, inspecting all orchards in these sections and examining large quantities of fruit. The result of these investigations is given in the following pages.

\section{HISTORY OF THE TRYPETA LUDENS.}

The fact that oranges in some portions of Mexico were infested by maggots has been known for a very considerable time, but the insect was not classified and described until 1873, when the Austrian naturalist, Loëw, one of the leading authorities on dipterous insects, first described it under the name which it now bears, Trypeta ludens. Since the date of its first description by Loëw, a great deal of attention has been given it by entomologists, and during the past few years, or since California has taken measures to prevent its introduction into this State, it has become a matter of international importance.

This insect belongs to the natural order Diptera, or two-rvinged flies, and is related to the common house fly. It also belongs to the family Trypetidx, a very numerous family, the greater part of which is destructive, the larvæe either working on fruit or vegetables, or forming galls on the plants which they attack. In fact, the greater part of the fruit flies which have done such great damage in some countries belong to this family. In our own country we have but one fruit fly which has proved serious, the Trypeta pomonella, which, in some of the Eastern States, is a very serious pest of the apple. The group is a very large 
one, and many genera are found in the United States. As a rule the flies are small, although some of the members of the family are of large size. They are usually beautifully marked, the wings being spotted or banded, as shown in our illustrations of Trypeta ludens.

While not described before 1873 , the insect and its ravages were well known in Mexico for many years prior to that time, as it was found in several varieties of fruit in the tropical sections, the mango and guava being especially subject to its attack. So serious was it upon these fruits that it was difficult to find a specimen which did not contain from one to ten or twelve worms. In fact, it is generally asserted by Mexican entomologists, and by people living in the infested sections and who have observed it closely, that the mango is its primal food plant, and that the orange is secondary. It is certain that it attacks all three of the fruits mentioned and continues its existence in the mango and guava during the period when oranges are small, green, and unstitable for food for the larve of the fly.

Fruit is attacked by this insect in the early ripening period, and as it can not exist in the green fruit, the female fly lays her eggs upon the orange at the time the fruit begins to turn color; in the early season her eggs are laid in the mango and guava, which ripen during the immature period of the orange. The general opinion, and one which is supported by the habits and life of the insect, is that it is of tropical origin and has followed its food supply from the equatorial regions of South America into the tropical sections of Mexico, where it has now become firmly established.

While, as stated, this insect and its ravages had been known to the inhabitants of tropical Mexico, it had not been scientifically noted or described until 1873, when it was worked up by Loëw. It was largely a local plague for many years after this, and attracted but little attention; in fact, it was not until California, in the interests of her great orange industry, prohibited the importation of Mexican oranges into her territory that it came into prominence. Since then Trypeta ludens has figured extensively in reports and newspaper articles until it has become one of the best known insects. Our orange-growers have stood in dread of the introduction of this pest as one of the worst possible evils that could befall them. How far these fears are well grounded, and how far they are exaggerated, it is the object of the following pages to show. In any event the agitation has been salutary in that it has forced upon the Mexican Government, and, through this source, upon the Mexican orchardists, the absolute necessity of using every means to check, if they can not actually annihilate, this scourge, and they have worked with such good results that danger to California fruit interests from this insect has been reduced to a minimum. Every possible means has been resorted to to keep down the pest, even to 
destroying all fruits which it infests, and this work will be continued, so that, so far as human efforts can avail, the spread of the fly will be checked.

In a paper on the danger of importing insect pests, published in the Yearbook of the U. S. Department of Agriculture for 1897, Dr. L. O. Howard, Chief Entomologist of the Department of Agriculture, gives the following, which practically covers all that was known of this insect at that time:

For a number of years it has been known that Mexican oranges sold in the New Orleans market occasionally coutained maggots. The writer ascertained this when visiting New Orleans as long ago as 1881 , but was unable to secure specimens. In 1887 Prof. Lawrence Bruner, then an agent of the Division of Entomology, while visiting Mexico, secured infested fruit, took it home with him to West Point, Nebr., and succeeded in rearing the adult insect, which proved to be a two-winged fly, described in 1873 from Mexico by Loëw, the Austrian naturalist, as Trypeta Tudens.

According to Bruner's report, this insect was most abundant in the oranges raised in the State of Morelos, one hundred miles south of the City of Mexico, and the statement was made to him while in the City of Mexico that oranges from Morelos were very liable to be thus infested. An article upon the insect was published by Riley in the first volume of Insect Life (July, 1888), but no further information as to the natural distribution of the species was gained for a number of years. In late December, 1894, and again in February, 1895, the orange groves of Florida suffered, as will be remembered, to a very serious extent from severe cold. Hundreds of thousands of trees were killed and the orange crop of that year was practically annihilated. It resulted that during January, February, and March, 1895, and again during December, 1895, and January, 1896, orangebuyers spread out into the West Indies. Islands, and many of them went to Mexico. The shipments of Mexican oranges into the United States took an enormous jump, and the markets of our Northern and Eastern States were largely supplied with this fruit. Many persons saw the Morelos orange fruit worm in oranges upon their tables for the first time during these winters, and many newspapers contained accounts of the supposedly new insect. In only one case, however, so far as we know, was an effort made to trace the exact source of the infested fruit.

Prof. W. G. Johnson, now of the Maryland Agricultural Experiment Station, but then assisting Prof. S. A. Forbes, at Champain, Ill., found the worms in his own breakfast oranges, traced the stock to a particular dealer in Chicago, and from him learned that the consignment of which these oranges were a part came from just south of the City of Mexico-presumably the State of Morelos.

For some years past the Mexican oranges have reached the California market early in the fall, before the California fruit has ripened. Shipments have been begun as early as October and have continued up to December, when the California fruit is fit for consumption. The occurrence of some of these Morelos maggots in some of this fruit was pointed out in certain of the California papers during the fall of 1896 , with the result which has already been indicated.

The shipment of this Mexican fruit through to the northern United States can do no possible harm, since this species, so far as known, breeds only in citrus fruits. Even did it attack other fruits, such as peaches, pears, and apples, as some of its close allies are known to do, the fact that the oranges are shipped in the winter would bar its introduction. During the seasons following the Florida freezes this fruit was even carried into Florida and was found on the tables at the principal winter resorts in that State. So little native fruit was left in the State, however, that eren this could not be considered as very dangerous. The carriage of infested fruit into the State of California, however, is quite another matter. It arrives there just before the California fruit begins to ripen. A Mexican orange containing these maggots thrown away even at some distance from an orange orchard might result, as can be readily seen, in the establishment of this destructive species in California. There is little wonder, then, at the interest felt in the matter by the fruit-growers in that State. 
In 1894, as we have already stated, an agent of the Division of Entomology was sent to Mexico for the purpose of investigating the insects injurious to agriculture. This agent, Prof. C. H.T. Townsend, reported incidentally upon this insect, although his trip was made before the "scare," if we may call it so, had developed. He showed that oranges were shipped from Guaymas and Hermosillo, in Sonora. Sonora oranges were sent to Chicago and other Eastern points, some going, however, to California to the San Francisco market. The Morelos oranges, according to the information which he was able to gain, were shipped only as far as the City of Mexico. This, however, we have already shown was a mistake. From the Guadalajara region oranges were shipped by the carload through to northern points, mainly to Kansas City. The same was the case with the oranges of Tamaulipas. He could find no evidence ihat Trypeta ludens infested any oranges except those from the State of Morelos.

During the winter of 1895-96, however, it was learned from American orange-buyers that the Morelos fruit worm existed also in the State of Puebla.

During his travels in the summer and fall of 1897 in Mexico, Mr. Albert Koebele was good enougb to further investigate this question of the distribution of this insect. He was informed by the agent of the Wells-Fargo Company, at the City of Mexico, in October, 1897, that but few oranges are now shipped by this company. A few years since, however, large quantities from the State of Morelos were delivered to their office by the Interoceanic Railroad, to be shipped to the United States via El Paso, their ultimate destination being unknown to the agent. The freight agent of the National Railroad informed him that but few oranges were shipped from the State of Morelos; many, however, were shipped from the States farther north, principally for New Orleans and Central States.

The agent of the Interoceanic Railroad informed him that some of the fruit was shipped by his railroad, chiefly from Jalapa, and thence to Vera Cruz, and no doubt from that place by steamer to New Orleans and other points. It was by this road that, in Mr. Koebele's opinion, the largest quantity of the Morelos oranges were exported, since their lines run through the States of Morelos and Puebla. This agent stated that about one hundred carloads are shipped annually from Jalisco. He was informed by the agent of the Mexican Central Railroad that but few oranges were shipped from the City of Mexico, although a great many were shipped from farther north, and especially from the Guadalajara branch, chiefly to St. Louis and Chicago. An experienced fruit nierchant informed him that he had found the larva in Morelos oranges and also in considerable number in those from Michoacan, Puebla, and Jalisco. The same merchant also informed him that the National Railroad buys large lots of oranges in the City of Mexico for shipment.

This represents our actual knowledge of the distribution of the species in Mexico down to the autumn of 1897. Appreciating the desirability from every point of view of exact information on this in portant question, Professor Townsend was commissioned to visit in November and December, 1897, every orange-growing district of Mexico, with the exception of Sonora, and to examine into conditions with relation to this one insect. He carried out his mission with success, and found, as anticipated by the writer, that the orange fruit worm occurs practically wherever oranges are grown to any extent in Mexico. Good evidence was gathered of the existence of the species in the following localities: Morelos, Cordova, Yautepec, Coatepec, Teoselo, Amacusac, Puente de Ixtla, Toliman, Jalapa, San Luis Potosi, Pueblo Nuevo, Cuernavaca, Monterey, Linares, Montemorelos, Chiluahua, Guadalajara, Escalon, San Cristobal, Anseca, La Barca, Victoria, Tuxpan, Jalisco, Mảnzanillo, Acapulco, and Guerrero. The fruit flies have actually been reared in Washington, D. C., from oranges received from Professor Townsend from the City of Mexico, from Cordova, from Jalapa, and from Tampico. There is, however, no certainty as to where the Tampico oranges were grown.

Mexican orange-growers have become more interested in the subject of the California opposition to their fruit, and are naturally, though not justifiably, indignant at the California call for quarantine or prohibition of their fruit. One of the leading industrial papers of Mexico, El Progreso, contained a leading article last spring insisting that the true cause of the California movement was "the lesire which these horticulturists have of freeing themselves from the competition which grows more threatening for thiem day by day, and not that of escaping from the problematic infestation."

The knowledge of the exact details of the life history of Trypeta ludens nay prove of 
value in this apparent emergency. Unfortunately, the insect has not been carefully studied in its native home by a competent entomologist. Bruner brought back with him, in the early winter, specimens of oranges containing larvæ, and from these bred the adult fly the following February. All of the oranges showed a more or less welldefined outward sign of the depredations of some insect enemy. In one a freshly made hole coming to the surface was found, and one of the maggots was observed protruding. December 30th several of the larvæ had pupated, having left the fruit December $22 d$. The fruit itself had rotted and molded, and about one half of the pulp had been

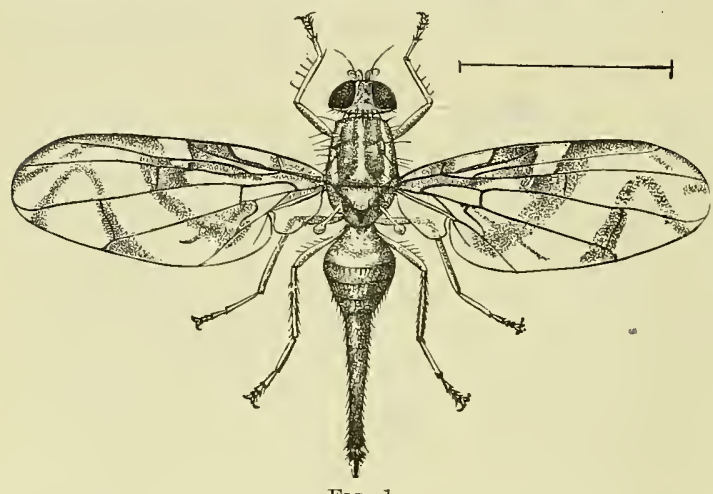

Fig. 1.

Female, enlarged. (Redrawn from Insect Life, by Howard.) devoured. The first adult appeared February 9th. The adults of both sexes were confined with ripe fruit to see if they would oviposit in the orange, if not on the tree. Experiments failed, however, and none of the flies laid eggs, all dying after several days. Johnson experimented with two infested oranges. In both instances the fruit was perfect, so far as outward appearances were concerned. There were no visible ruptures or punctures in the skin, and the flavor of the fruit was sweet and luscious. The mag-

gots when first noticed, on January 10th, were about one third of an inch long, of a dirty whitish color, and worked their way freely through the pulp. The fruit was placed in a dish with some larvæ, and after three or four days became very moldy; but the larvæ continued feeding until January 18 th, when two of them having reached the length of $11 \mathrm{~mm}$., left the oranges and burrowed into the ground, one pupating on the 21st, and the other on the 24th. The first adult, a male, issued February 28th, or just thirty-eight days after pupation. Four days later the second fly emerged.

The observations of both Messrs. Johnson and Bruner show that the fly is hardy and will stand considerable neglect. Mr. Johnson kept a male and female for several days in close confinement in a glasscovered dish, and they were seemingly as active as ever when removed. Mr. Bruner showed that the flies can stand a considerable variation in temperature, since on several occasions during his experiments the mercury fell below the freezing point in the room where his breeding cage stood.

The oranges received at Washington from Professor Townsend from the City of Mexico, Cordova, Jalapa, and Tampico all arrived between November 26 and December 21, 1897. The first flies were reared January 12, 1898, and between that date and February $3 d$, twenty-five active specimens emerged, of which fifteen were females.

The different stages of the insect, with the exception of the egg, are well indicated by the figure. The larva is dirty white, the puparium is light brown, and the adult fly is a straw yellow in its general color. The bristles upon its body are black and the stripes upon the body are silver yellow. The markings upon the wings, as shown by the figure. are brownish yellow, with brown edges. 
So far, the knowledge which we possess of the life history of the Trypeta ludens is rather general than specific, as it has not been studied as yet by an entomologist. Probably Professor Herrera, of the Parasitological Commission, has paid more attention to it than any one else, as it comes directly within the province of his department, and in a report to the Minister of Fomento he says:

Complying with the request of Sr. Ingeniero D. Manuel Fernandez Leal, Minister of Fonento, I made a journey to Yautepec, on the 19th of February, 1900, to acquire data and tables about the orange worm, and present the following as the result of my investigations :

(1) First, the orange worm exists in Yautepec.

(2) It is the Trypeta ludens, a dipterous insect.

(3) It attacks all varieties of oranges in all the orchards, and is also found upon the nango, the sweet lime, and the guava.

(4) In January and April they breed in the early orange, in May and June in the mango, and during the rest of the year in oranges as they ripen during the season, and in the latter part of the season they reach their greatest numbers.

(5) As preventive measures I advise the burning of all the early oranges, the cleaning up of all the orchards, the substitution of live hedges by wire fences, and the burning of all fruit which ripens prematurely on the trees. It is very probable that the enforcement of these measures for two or three consecutive years in all parts of the Mexican Republic invaded by this pest would result in its total extirpation.

The seriousness of the Trypeta ludens as a pest was first brought strongly to the attention of the Mexican Government by the action of the California State Board of Horticulture, when the discovery of worms in fruit imported from Acapulco caused an embargo to be placed on, all oranges from that country. As a result of the action of the State Board of Horticulture, the following letter was addressed by Fernandez Leal, then Chief of the Department of Fomento, to the governors of all of the Mexican States:

Mexico, January 18, 1900.

The Horticultural Board of the State of California, having discovered the presence of maggots in the Mexican orange, has prohibited the introduction of that fruit from Mexico into said State, and has ordered that all consignments of oranges from Mexico be destroyed upon their arrival. This measure, which has been adopted on account of the fear that the pest may spread to the California orange groves, has attracted the attention of the press of the State, which has sounded the note of alarm, suggesting that the American Congress take up the matter and pass laws to prevent the importation of fruits and plants that are tainted with insect or other pests that are capable of being propagated.

This department considers it unnecessary to enter into consideration of the harm that will accrue to Nexican trade in general, and especially to the growers of fruit, if they are excluded from the important market of the United States; your well-known enlightenment will easily enable you to appreciate the extent of the damage.

This department being desirous of contributing, to the extent of its powers, toward warding off an evil of such magnitude from the planters of the country, has deemed fit to address this circular to you, urging upon you the necessity of apprising all growers of the fruit in question of the steps taken by the Horticultural Board of California, and of encouraging them by all possible means to extirpate this pest which has justly alarmed said board.

Until such time as Mexican growers can attain positive results in said direction, this lepartment is of the opinion that, in their own interest, they should abstain from exporting oranges which show external signs of having been attacked by the dreaded 
insect. All the precaution that can be taken for that purpose will be amply compensated in the future.

I forward you copies of three articles published in Nos. 9, 10, and 11 of Volumes VII and VIII of the "Frnit World" of Los Angeles, in order that by such means as you may consider suitable you may secure their profuse circulation among all interested parties in the State which you so ably govern.

(Signed:) FERNANDEZ LEAL.

As a result of the attention thus called to this insect an active campaign has been waged against it in sections where it was known to exist, and a wider knowledge of its habitat and life history has been obtained. In fact, the Trypeta ludens has become one of the best known insects in Mexico, especially in the tropical sections where it prevails, and methods of combating it are discussed and resorted to. In some of the worst infested sections old orchards have been entirely abandoned and destroyed, while in all cases a systematic warfare is carried on against it. In aid of this work, the Mexican Government, through the Commission of Parasitologia, and under the direction of Professor Herrera, has kept a force of men at work through the whole season experimenting with various means to destroy the insect in any or all of its various stages. The principal work along this line has been carried on at Yautepec, in Morelos, the center of infestation, and from which point all wormy fruit in the markets of northern Mexico finds its way.

\section{ORIGIN OF THE PEST.}

(Translated from bulletin of the Commission of Parasitologia.)

"As the orange and mango are not indigenous to Mexico and the pest is not reported from other places, it is probable that it originated on some other fruit, likely the imported guava, and it is necessary to study this matter well, in order that measures may be taken to reach the pest in its original habitat.

"What cause is answerable for the spread of this pest? This is difficult to answer. It may arise from a mistaken instinct of the females which leads them from their natural food, or, on the contrary, it may be owing to their sagacity. For instance, not finding guavas upon which to lay their eggs, they have sought the next best food plant, being attracted by its odor or agreeable sensation.

"Mr. Rangel has not observed the larger Trypetio attacking guaras when oranges were handy. It is not improbable that there are different species adapted to various conditions.

"The older residents of Yautepec state that this pest was introduced there from Cuernavaca sixty years ago, and complain that the pest is still found there in quantity and is a source of infestation to the orchards of Yautepec.

"To prove that the pest of the mango and of the orange are identical we transferred the larvæ from the one fruit to the other, and they took 



\section{TRYPETA LUDENS}

(MEXICAN ORANGE PEST)
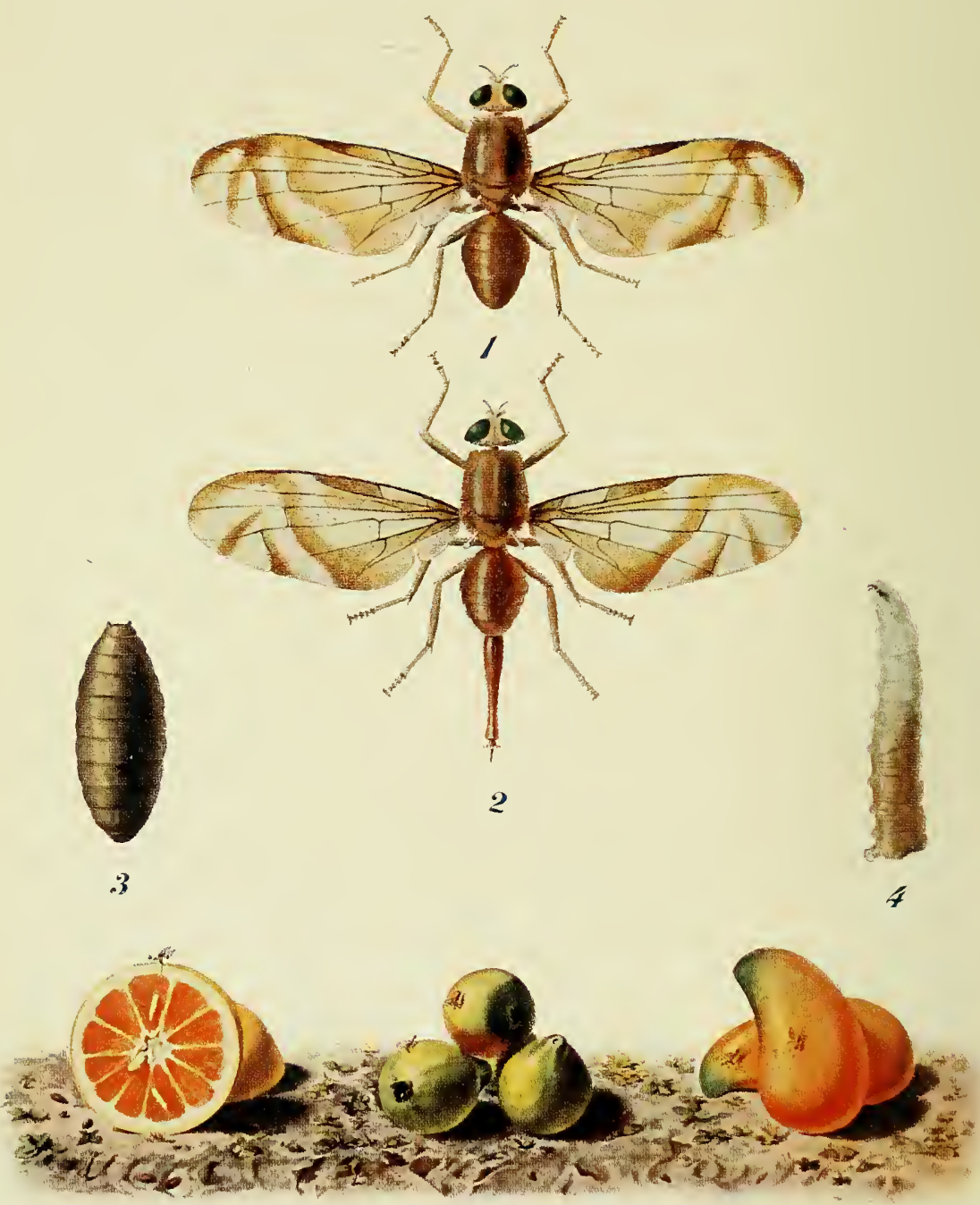

.5

6

$z$

From Drawing by the Comision de Parasitologia Agricola, Mexico. 
$+$

$k n=17=$

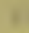

in

in $=$

$\operatorname{lin} x+2$

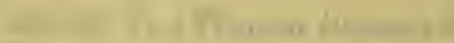

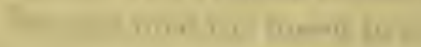

| $+1-n=1$

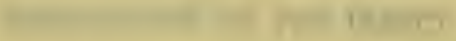

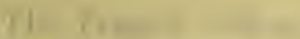

win mith

frowht in th t

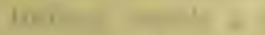

Dhen in it. 1

$\begin{array}{lll}0.11 & 11 & \end{array}$

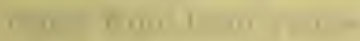

11 $0 \times 0 \%$,

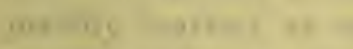

Y $m=m, \quad r$ I $m$

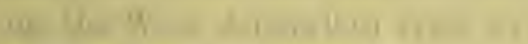

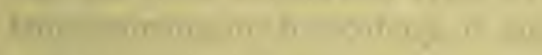

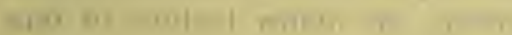

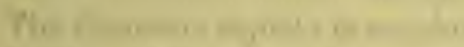

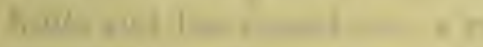

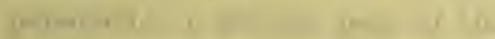

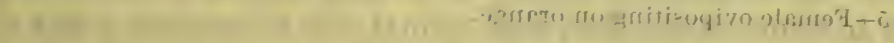

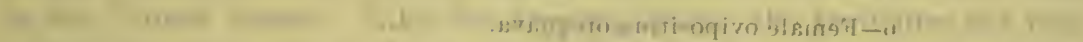

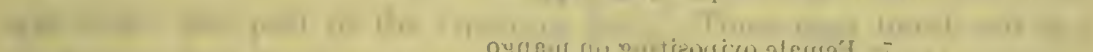

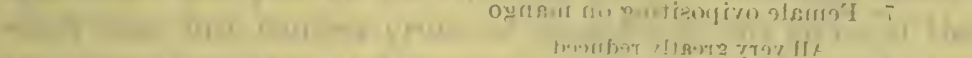

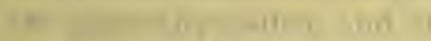

\section{.นหมดบ АТรฯหา}

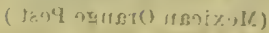

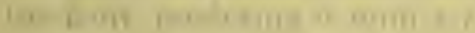

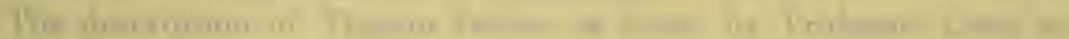

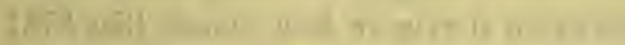

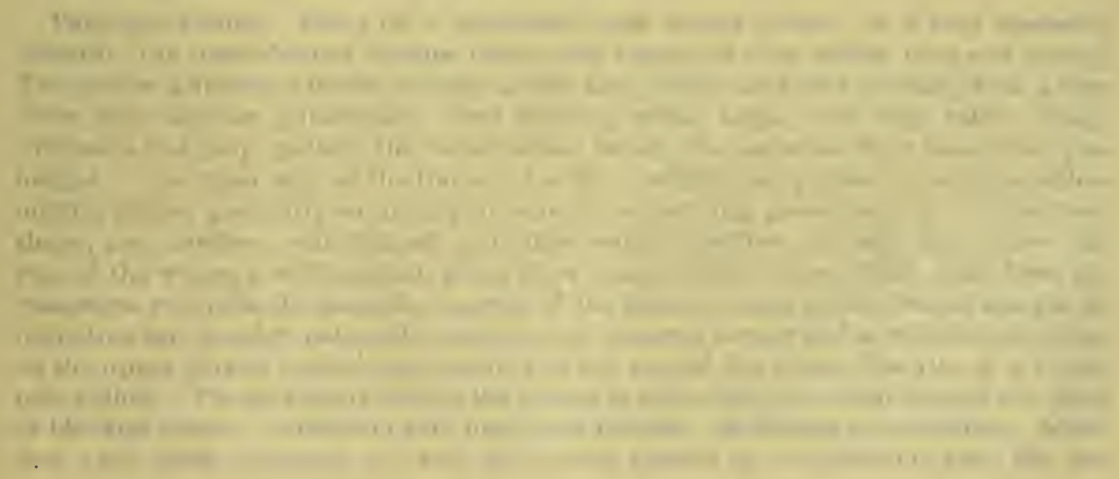




\section{TRYPETA LUDENS.}

(Mexican Orange Pest.)

1-Male, dorsal view.

2-Female, dorsal view.

3-Pupa.

4-Larva.

All very greatly enlarged.

5-Female ovipositing on orange.

6-Female ovipositing on guava.

7-Female ovipositing on mango. All very greatly reduced. 
equally well to both and we bred the mature fly (Trypeta ludens) from larvæ in mangoes from Cuernavaca. We also bred the insect in guavas, transferring three of the larvæ from the mango to the guava, into which they burrowed in four to five minutes.

"On July 23d, a guava was found infested with worms, and from this we bred the flies which emerged on August 31st."

\section{DESCRIPTION OF THE INSECT.}

The Trypeta ludens is a dipterous, or two-winged, insect, belonging to the somewhat numerous family Trypetidæ. The members of this family are mostly small insects, although some of them, as Trypeta ludens, reach a good size. All of them are vegetable-eaters, many of them in the larval state attacking fruit, and others working on the stems of plants, forming galls. They vary in color, as in size, and range from light yellow to dark brown. In the lighter species the body is often spotted, while the wings are spotted, banded, or otherwise prettily marked, as shown in the illustrations herein. Within this family are discovered some of the worst fruit pests in the world, including the West Australian fruit fly (Tephritis tyroni), which has made fruit-growing in that colony, if not impracticable, at least unprofitable, and to control which the government has expended immense sums. The Ceratitis capitta is another member of the family which attacks soft fruits and has spread over a great portion of the world. The Trypeta pomonella, a serious pest of the apple in some of the Eastern States, is also a member of this family, and perhaps the worst at present found in the United States. Like the Trypeta ludens, the fruit flies lay their eggs under the peel of the ripening fruit. These eggs hatch out in a short time into footless grubs, or maggots, as the larvæ of the diptera are generally called, and these maggots proceed at once to tunnel into the fruit, rendering it unfit for consumption.

The description of Trypeta ludens as given by Professor Loëw in 1873 still stands, and we give it herewith:

Pale clay-yellow. Front of a somewhat more bright yellow, of a very moderate breadth; the usual frontal bristles black, only the upper ones rather long and strong. The yellow antennæ almost as long as the face; arista long and slender, witl a very short and delicate pubescence. Oral opening rather large; oral edge rather sharp. Proboscis and palpi yellow, the latter rather broad; the suctorial flaps somewhat prolonged. The upper side of the thorax of a light, bright clay-yellow; a sulphur-yellow middle stripe, gradually vanishing anteriorly, expanding posteriorly in a cuneiform shape, and nowhere well defined; scutellum sulphur-yellow; on each side, above the root of the wings, a well-marked, pale-yellow longitudinal stripe, which runs from the transverse suture to the posterior margin of the thorax; quite on the lateral margin an indistinct but broader pale-yellow stripe; the humeral corner and a well-defined stripe on the upper part of the pleuræ, reaching to the root of the wings, likewise of a bright pale-yellow. The very short pile on the thorax is yellowish; the usual bristles are black or blackish brown. Scutellum with four black bristles. Metathorax clay-yellow. Abdomen with short yellowish pile and with black bristles on its posterior end; the last 
segment very much prolonged, much longer than the two preceding ones taken together (this character serves easily to distinguish this species from $T$. fraterculus, which is very much like it). Feet yellow, nnder side of the front femora with several blackish-brown bristles. Wings not very broad in comparison to their considerable length; the rivulets on then are pale brownish-yellow, with narrow, but little conspicuous, and not always perceptible brown borders; near the posterior margin and on the apex of the wing they are altogether brownish; the hyaline spaces between the rivulets are as follows: 1 . An oblique band, interrupted upon the third longitudinal vein, the anterior part of which forms, immediately beyond the stigma, a spot extending from the costa to the third longitudinal vein, while the posterior part of the band occupies the portion of the basal cell which lies under the stigma, the basis of the discal cell and the second basal cell; 2. A broad S-shaped band, which begins at the posterior margin, between the tips of the fifth and sixth longitudinal veins, passes between the two cross veins, reaches the second longitudinal vein, turns backward and reaches the margin in the vicinity of the end of the fourth longitudinal vein; 3. A large triangular spot near the posterior margin, which fills a considerable part of the second posterior cell, reaches with its tip considerably beyond the fourth longitudinal vein, and almost coalesces here with the S-shaped hyaline band. The external costal cell also is hyaline, with the exception of its basis, but has a more yellowish tinge than the other hyaline spaces. Stigma rather long, almost imperceptibly darker than its surronndings. Cross veins straight and steep; the third longitudinal vein distinctly bristly; the end of the fourth longitudinal vein turned forward; the posterior end of the anal cell drawn out in a very narrow, long lobe.

The comparison of the description of Trypeta fraterculus and T. ludens shows the great resemblance of the two species and an entirely satisfactory distinctive character in the different length of the last abdominal segment. The females of these species, which nnfortunately I have not seen, will probably be easy to distinguish, if attention is paid to the size, which is larger in $T$. ludens, to the somewhat broader cheeks, the longer last abdominal segment of this species, and to the course of the third and fourth longitudinal veins, which suddenly diverge here, while their divergency in T. fraterculus is much more gradual. In using the coloring for distinguishing the two species, a certain caution is necessary here, as well as in the other species of this group.

\section{NUMBER OF GENERATIONS.}

The Trypeta ludens completes its life cycle from egg to perfect insect in about three months, so that there may be four generations within the year. It is stated that it has no dormant period, but breeds continuously, and that if there is a break in its food supply it must necessarily perish. Its eggs are laid and the young larvæ live in the ripening fruit. It does not attack fruit until it begins to ripen, avoiding all green fruit as unfit food. In tropical Mexico the mango and guava ripen between the period of the early and the late orange season, thus bridging over the interval and furnishing a continuous suitable food supply. The Mexican authorities, basing their argument upon this fact, assert that inasmuch as there is in California a very long period when there is no suitable fruit ripening, the pest could not exist here, and would perish in the interval between one orange season and another.

Samples of infested guavas have been sent to the Bureau of Entomology at Washington, D. C., and the insects produced from them have belonged to another species, Trypeta acidusa, and from this fact some little doubt has been cast upon the Trypeta ludens attacking the guava; but from continued experiments carried on by Professor Rangel, all 


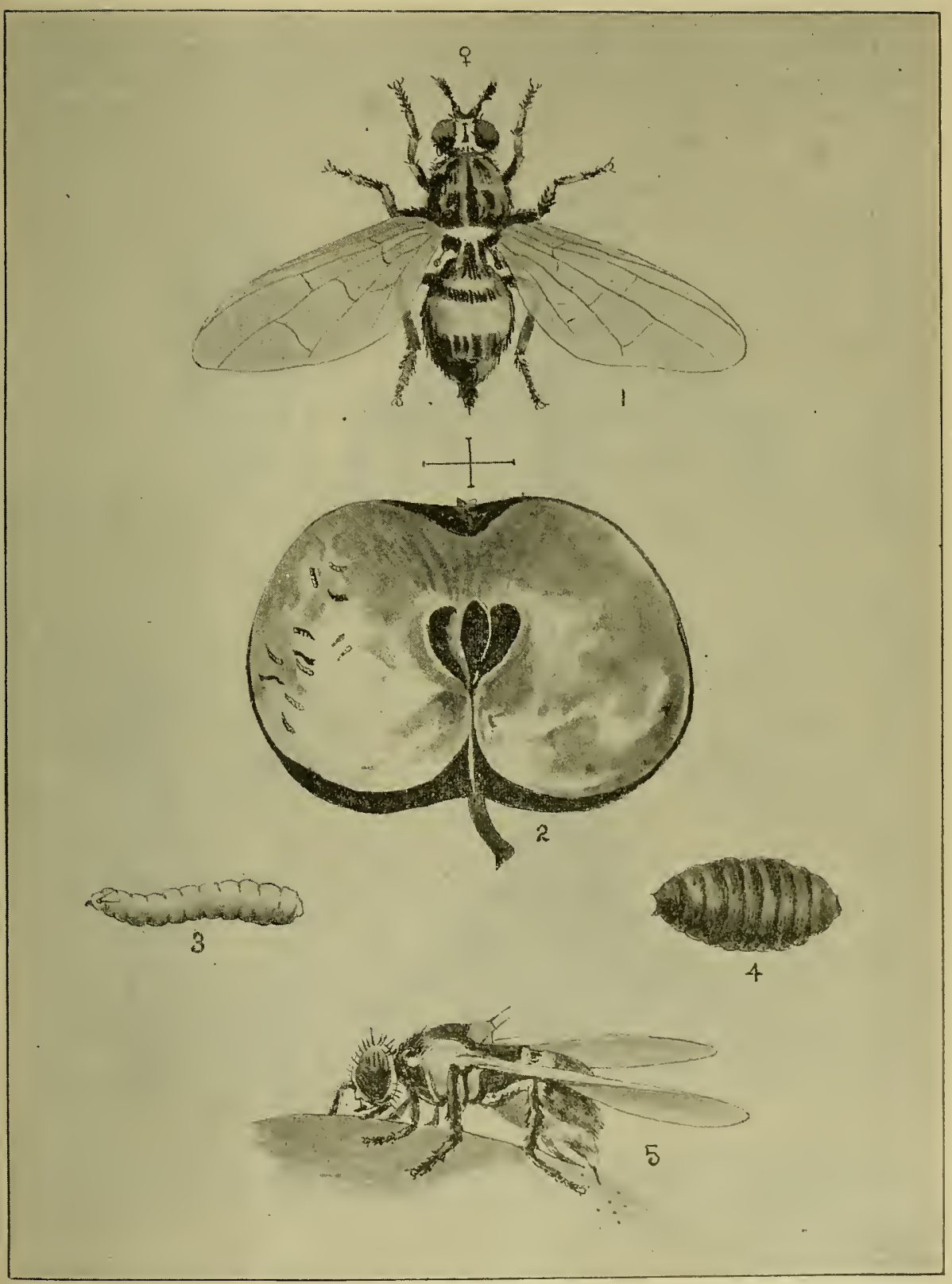

PLATE II. Queensland Frutt Fly (Tephritis tryoni).

1, the fly enlarged; 2 , section of apple infested by maggots, natural size; 3, maggot, enlarged; 4, pupa, enlarged; 5 , the fly in the act of depositing eggs in the apple, enlarged. (Keclrawn from the Town and County Journal, of New South Wales.) 
doubt upon this point has been removed and it is now certain that the guava is attacked by both species.

The larvæ of Trypeta ludens assume the color of their food plant, and in the orange are deep yellow, while in the sweet lime and guava they are much lighter in color. It is owing to this fact that it is sometimes
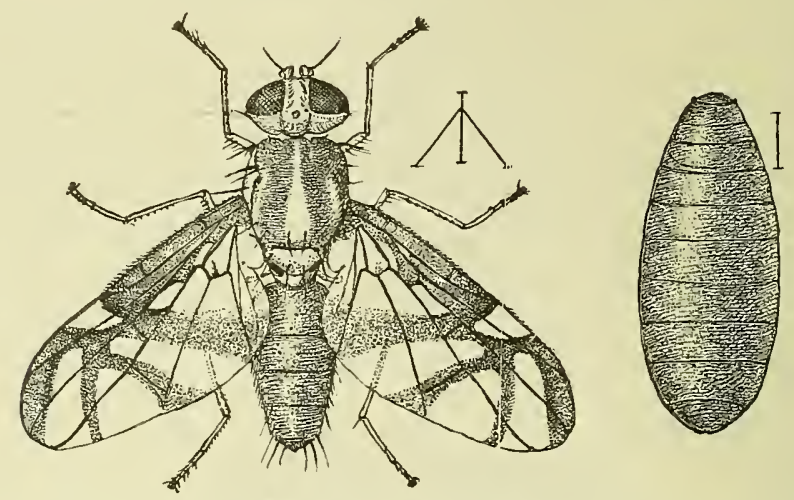

FiG. 3. Trypeta acidusa.

Puparium at right, adult at left, greatly enlarged. (After Howard.)

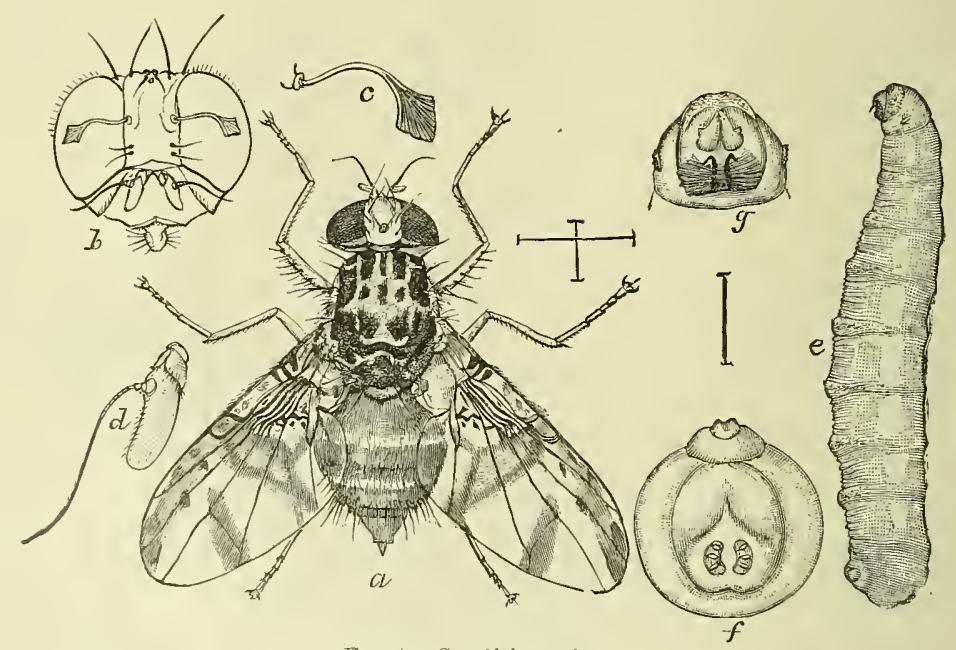

FIg. 4. Ceratitis capitta.

$a$, adult fly; $b$, head of the same from front; $c$, spatula-like hair from face of male; $d$, antennæ; $e$, larva; $f$, anal segment of same; $g$, head of same; $a$ and $e$ enlarged; $b$, $g$, and $f$ greatly enlarged; $c$ and $d$ still more enlarged. (Redrawn
from Insect Life, by Howard.)

difficult to discover the small larvæ in the fruit. As the larvæ increase in size, the condition of the fruit is sufficient to indicate their presence.

A report of the Commission of Parasitologia states that the Trypeta ludens, after completing its larval stages in the fruit, passes into the pupa in the ground, and pupæ were bred out under glass in the City of 
Mexico, remaining in pupal form for from thirty to forty-six days. In the warmer and moister soils of the tropics the insect passes through the period of transformation in from seventeen to twenty-five days.

The average life cycle of the insect covers a period of three months, making four generations in the year. There is, however, no sharply defined season between the broods, but their appearance is continuous. The earlier-appearing flies attack the late oranges, which are ripening in the vicinity of Yautepec in April or May. Later, or during the period that there are no ripening oranges, they confine themselves wholly to the mango and guava, from which they spread again to the oranges as they are ripening in November and December.

Professor Herrera has made a curious calculation as to the possibility of infestation from a single female fly. He says:

By way of estimating the possible descendants of a single progenitor, we made a microscopical examination of the abdominal contents of a female fly, and counted serenty eggs. Supposing that all of these would hatch, and that the males and females were equally divided, each pair in turn would prodnce seventy descendants, which would be 2,450 for the second generation and 85,750 for the third, which would be in about nine or ten months. We have found the following coefficients very useful in practice, but it should be borne in mind that not all eggs or larvæ become flies.

To ascertain the number of the first generation in three months, multiply the number of parent insects by 35 , the second generation by 1,225 , and the third by 42,875 . For example, from 3,000 larvæ received from Professor Rangel, there would be 105,000 of the first generation, $3,675,000$ in the second, and $128,625,000$ in the third, after a period of nine to ten months.

To ascertain the coefficient correspondence of each generation multiply by 35 , as follows :

Second generation $\ldots \ldots$
Third generation
Fourth generation $\ldots \ldots \ldots$
$1,225 \times 35=$$\quad \begin{array}{r}3,225 \\ 42,875\end{array}$

This means that the descendants of the 3,000 larve at the fourth generation, or inside of one year, would amount to $3,000 \times 1,500,625=4,501,875,000$.

One great circumstance which prevents the plague from spreading is the fact that the greater part of the wormy fruit is exported to distant places where, for many reasons, it can not transform from the larva and perishes before it reaches the perfect stage. But should it happen some year that exportation were suspended on account of increase of duty or by an interruption in the means of communication, then it might happen that all of the fruit in the State of Morelos would be attacked and also that of the immediate states, and not only would the orange be lost, but also the mango, guava, and other wild and cultivated fruits. Thus the descendants of 3,500 larvæ received at this office and preserved in alcohol wonld be sufficient to infest 1,020,377,000 oranges, allowing five larvæ to each orange.

What is deduced from these calculations is that were the plague exterminated in any locality, and but a single pair of insects had been overlooked, this would be sufficient to rapidly infest the country again.

From information received from the State of Morelos a great deal of loss is suffered from the plague each year, and this loss is uniform each season, modified only by variations of slight importance.

In Cuernavaca hardly $\$ 1,000$ worth of mangoes can be gathered free from the pest, although the total production is at least five times that amount. The orange can not be grown liere on account of the worms.

Mr. Guillermo Gandara informs ns that in a great many of the orchards at Cuernavaca the plague has spread to snch an extent that the owners have been compelled to discard 
the cultivation of mango trees, or if they desire this fruit they gather it when green and place it between plantain leaves to ripen. In this district in a few days Mr. de la Barreda collected and destroyed by burning between seven and eight thousand mangoes, all of which were infested. Professor Rangel removed over 3,000 larvæ from mangoes in Yautepec, and destroyed over 57,000 in which the worm was known to exist. According to a statement made at an assembly of agriculturists at Yautepec in February, 1900, the loss of fruit from this source alone in this district is from 33 to 40 per cent, or over $\$ 20,000$.

Even these large losses will fall below the reality, for they do not include the fruit which drops from the tree during the year all through the State of "Morelos.

\section{DISTRIBUTION.}

In the course of my investigations, I entered Mexico on the line of the Mexican Central Railroad and purchased a large number of oranges at the various stations along its whole length. I could not ascertain where these were grown, but as few oranges are produced in Chihuahua, Durango, or the other States through which this line runs, they were probably grown in Sonora, which is one of the principal orangeproducing sections of the Republic. The crop in this section was at its height, and I had good facilities for making my examination; but in several hundred oranges examined, I found no signs of infestation. I had the same experience in all my investigations in the higher lands, or the tierra templada of Mexico.

In the State of Morelos, however, the worm is a very serious pest. Yautepec, in this State, is the largest orange-producing section of the Republic. It lies wholly within the tropics, and it was from this point that the plague was first reported. Here the orange and the mango grow in juxtaposition, and both are very seriously infested by the orange worm, which is also found in the sweet limes. The orange season is earlier here than in the tierra templada or highlands, the fruit ripening in November and December. The great bulk of this crop was therefore off the trees at the time of my arrival, but I found sufficient evidence to show that the pest is a very serious one and does great damage to the crop. It is here that the Mexican Government has been carrying on extensive operations looking to the subjugation of the plague, and a force of twelve men, operating under two superintendents, has been kept continuously at work by the Commission of Parasitologia, experimenting with various expedients to check or destroy the pest.

I also found the pest in other parts of tropical Mexico-at Orizaba, Cordova, and other points in the State of Vera Cruz. I also learned of its presence in most of the tropical sections of Mexico.

During my investigations I made inquiries of many Americans whom I met as to the prevalence of the plague, and the result of these inquiries was to the effect that the fruit offered in the City of Mexico and along the lines of the railroads in November and December was often infested with worms, and sometimes very badly infested; that later in the sea- 


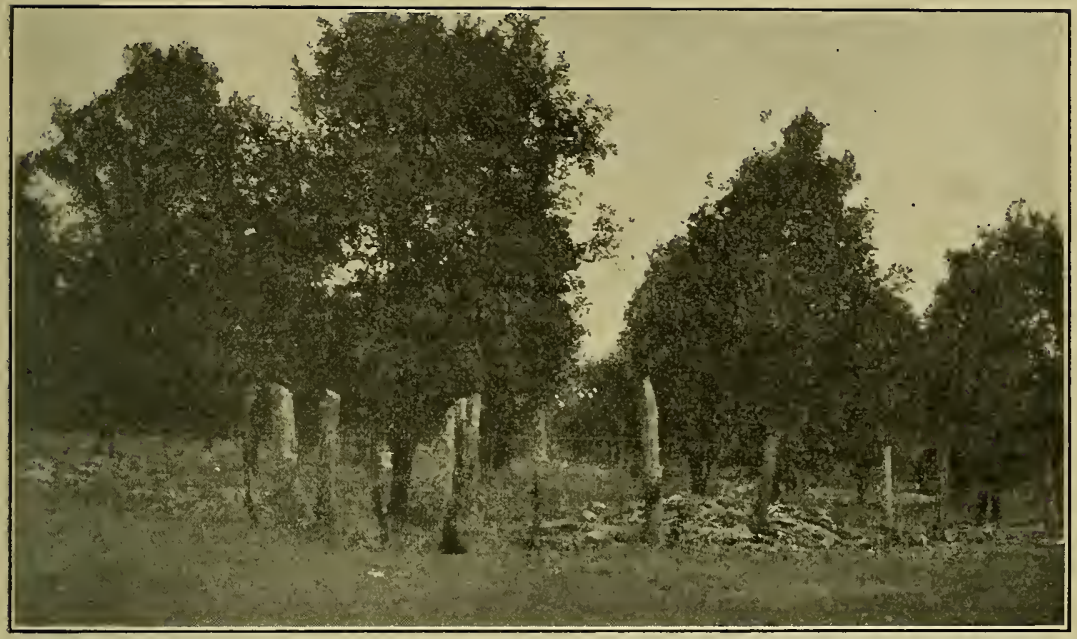

Orchard at Yautepec, Morelos.

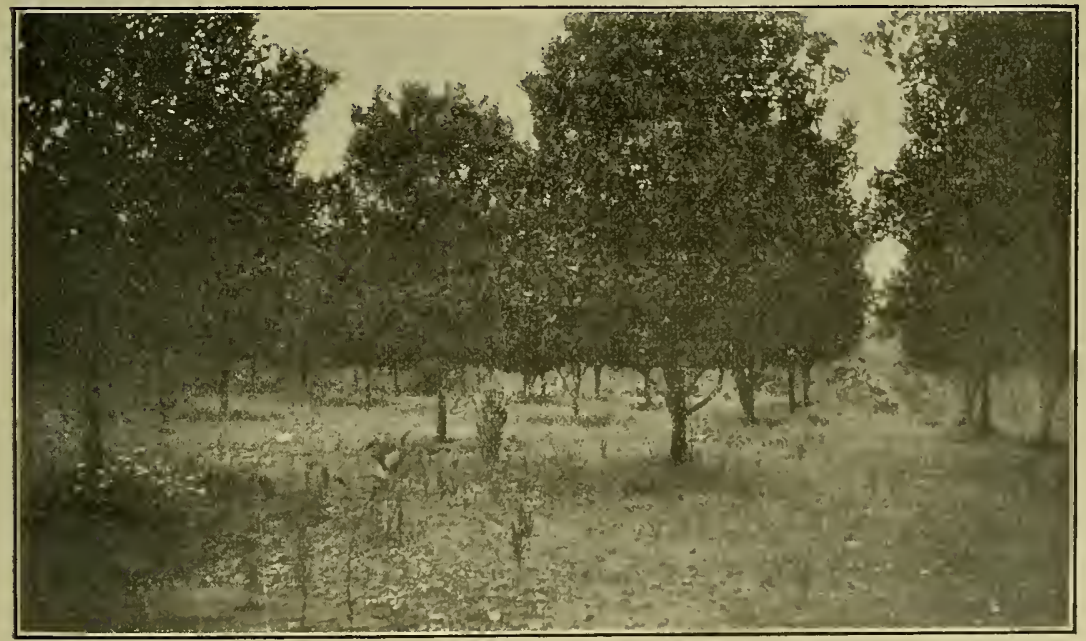

Orchard at Jalapa, Vera Cruz.

PLATE III. Orange Orchards in the Ixfested Districts. 
son the fruit was free, and that this season the oranges had been more than usually free from infestation. This largely bore out my own investigations, as all the fruit which I inspected in March and April was free from worms, except the few specimens which I found in the tropics, and which were the remains of the old crop.

Mr. Albert Koebele some years ago made an investigation into this matter during a trip to Mexico, and he informs me that he found the Trypeta ludens only in the tropical sections, the tierra caliente, and from his investigations at that time he came to the conclusion that it did not exist in the orchards of the higher lands. Dr. L. O. Howard, Chief Entomologist of the Department of Agriculture at Washington, D. C., bears out the statement of Mr. Koebele, and assures me that in his investigations, made several years since in the State of Sonora and portions of the high plateau, he did not find the worm, and it is his opinion that as yet its ravages are confined to the tropical sections of the country.

Infested fruit has been found at various times at points along the line of the Mexican Central Railroad, and even in shipments made from the Mexican groves into the United States, and has been quite common in the City of Mexico, but there is no evidence that this fruit was produced near the places where it was found; in fact, oranges are not grown to any extent along the line of the Mexican Central, north of the City of Mexico, and this infested fruit was, in all probability, grown in and shipped from the State of Morelos, the central point of infestation of the Republic. This supposition is strengthened by the fact that infested fruit has been found during the months of November and December, the time at which the Morelos fruit is ripe and being shipped.

Another thing that would seem to indicate that the State of Morelos is responsible for the greater part of the infested fruit is the fact that my inquiries of Americans in the City of Mexico about the prevalence of wormy fruit there were all met with the statement that during the past season the fruit was much freer from the plague than in former years. This may be accounted for by the energetic action which the Commission of Parasitologia has taken to stamp out the pest during the past year, and the decreasing amount of wormy fruit in the market would indicate that Morelos was the point from which it was shipped.

My attention was called to another fact by Mr. A. V. Temple, Industrial Agent of the Mexican Central Railroad. Mr. Temple has spent over thirty years in Mexico, and his duties have led him to make close observation of everything which had bearing on the business of his company. He is also a practical horticulturist and farmer. He informed me that he had been acquainted with the orange pest and its work for some years past, and had noted that it was not found except 
in the vicinity of mango trees, and that where there were no mango trees near the orange orchards there were no worms in the oranges. What there is in this statement I am not prepared to admit, but from my own investigations I am assured that the Trypeta ludens is primarily a pest of the mango, which it leaves to attack the orange at the time the latter fruit is ripening. The mango is a tropical tree and is not found in the higher Mexican plateaus, while in the tierra caliente the mango and the orange are always found in close proximity. Whether the Trypeta ludens would continue its ravages upon the orange if remored from the vicinity of the mango is still an open question, but if it should be true that it will not, it would remove from us a serious danger.

In relation to his investigations into the spread of the Trypeta ludens on the Pacific coast of Mexico, Dr. L. O. Howard says:

During April, 1898, the writer visited Guaymas, San Jose de Guaymas, and Hermosillo, Sonora. In the course of this journey he satisfied himself beyond a reasonable doubt that Trypeta ludens has not yet made its appearance in the orange-growing regions of the State of Sonora, so that there need be no fear, for the present at least, of the introduction of this destructive insect into California in Sonora oranges.

From the investigations made and the best information obtainable, it appears that the pest exists in the States of Guerrero, Morelos, Oaxaca, Tabasco, Tamaulipas, and Vera Cruz, and quite probably, also, in Campeachy, Tlaxacala, and Yucatan. It may also exist in some portions of Jalisco, Puebla, and Tepic, although it has not been reported from these States. The other Mexican States are so far apparently free from the pest. The infested section from which California would have most to fear is the State of Guerrero, as its port of Acapulco is one of the principal shipping points in Mexico, and there is continuous intercommunication between it and California points. From the States of Vera Cruz and Tamaulipas, on the Gulf of Mexico, no fruit reaches California, but the greater part shipped from there is sent by sea from the cities of Vera Cruz and Tampico and finds its way to the Eastern market via New Orleans. Oranges from Morelos, the worst infested section of Mexico, find their way in the season along the line of the Mexican Central Railroad and might enter the United States through El Paso, and there is a slight possibility of their entry through this channel, but it is hoped that the strenuous efforts now being put forth by the Mexican Government to check the plague in this section will have good results and reduce even this danger to its smallest fraction and guarantee our growers immunity from even the apprehension of danger. From other infested, or possibly infested, States no fruit is shipped, as they are either too remote from railroad or sea transportation facilities to reach the market, or have not taken up orange-growing as a commercial proposition.

In all probability Trypeta ludens is a tropical insect, and, so far, its 
ravages are apparently confined to the tropical sections, as it has not been reported from any orchards in the higher and cooler portions of Mexico, the infested fruit found in the markets of these sections being shipped from the lower country. Professor Herrera, who has given this pest a great deal of study, is of the opinion that it is of South American origin and has followed the tropics up until it has reached its northern limit in Mexico. This view is concurred in by Mr. Koebele, and in the absence of positive information on the subject, Dr. Howard is inclined to favor the theory.

Being a tropical insect it is claimed by the Mexicans that it will not endure the low temperature which sometimes obtains in California, and Professor Herrera states that from experiments carried on by him he has demonstrated that at a temperature of $37^{\circ}$ the fly will become dormant, and will perish with a still lower temperature. At Yautepec, the orange section of Morelos, thermometric readings kept for many year's show the lowest temperature to have been $46^{\circ}$, and the highest $86^{\circ}$ in the shade, and $117^{\circ}$ in the sun. A fall of the temperature to $43^{\circ}$ is very exceptional, and at this temperature the flies become dormant and incapable of action. Whatever there may be in this claim, the fact that worms have been found alive in Mexican oranges as far north as Chicago in the winter season would seem to prove that, protected by the pulp of the orange, the larvæ are able to stand a degree of cold very much below that given as the extreme for the perfect insect. The experiments made by Professors Johnson and Bruner in breeding out the fly from infested fruit in the latitudes of Chicago and Washington in the midwinter months of January and February would seem to indicate that the insect will pass through its changes at a very low temperature. We have no means of knowing at what temperature the breeding cases, in which the insects were confined, were kept, but it is probable that in the sections where they were it fell below $37^{\circ}$.

It is also claimed that, being a tropical insect, it will not endure in California, and in proof of this statement the fact is pointed out that while the insect has been known in the tropical sections of Mexico long prior to 1873 , when it was first described by Loëw, it has never spread beyond the tropics. No case of it has ever been reported from the plateaus, and no orchards in the tierra templada have ever been infested by it. It was also pointed out that, although there had been no restriction on the importation of Mexican oranges into New Orleans or Florida, the pest has never become established in the latter State, or in any of the groves of the Southern States. Past experience with tropical insects, however, goes to show that it is not always safe to rely upon their inability to withstand a climate differing from their natural habitat, and it sometimes happens that an introduced species finds superior advantages in a new country and becomes even a worse pest 
than in its native habitat. Some of the more serious of our introduced pests have originated in the tropics, a striking instance being the Diaspis amygdali, which has adapted itself to the Eastern climate and become one of the most serious of the scale insect pests, attacking all varieties of trees of the plum family and withstanding a zero temperature.

In his report on the pest in Mexico, Professor Herrera says:

From all information obtained up to the present writing, it appears that the plague is found in the warm sections of the south, which forms the center of its distribution. It is especially abundant in Yautepec and Cnernavaca (State of Morelos) and the country immediately surrounding. According to information obtained by $\mathrm{O}$. W. Barrett, at one time commissioned under this department to study this subject, the Trypeta ludens does not exist, nor ever has existed, in the State of Jalisco, although Mr. Townsend has erroneously stated that the plague exists in the whole Republic. Supplementing Mr. Barrett's statement, we have examined large quantities of oranges from Jalisco and have never found them infested.

It is probable that Mr. Townsend was misled by purchasing infested oranges in the markets, which had been produced in the State of Morelos or other southern points.

With regard to the probability of oranges being contaminated throughout the whole Republic because it abounds in the guava, we will state that there is a relative danger and that every means should be taken to destroy the pest where it exists.

The Commission of Parasitologia, under the direction of its chief, Prof. A. L. Herrera, has made an exhaustive study of the Trypeta ludens, and embodied the result of its observations in a bulletin, from which we translate the following:

California papers assert that should the orange pest succeed in entering California it would undoubtedly be practically the ruin of the citrus industry.

This is an exaggeration. In the regions of Yautepec and Cuernavaca, where climatic conditions are most favorable, from $\$ 30,000$ to $\$ 32,000$ of uninjured fruit are produced annually. In Jalapa, where the orchards are well cared for, while the pest is found in the guava it is rare in the orange.

It is further stated in the California papers that between 1881 and 1887 the worm plague has spread to all districts in the Mexican Republic where oranges are produced. Nothing could be more inexact than this statement, as the following will prove:

From experiments made by us, we assert that there is no danger of the orange fly becoming acclimated in California, and we also assert that it would not exist in a cool climate, or where orchards are properly cared for and kept clean. A tropical climate like that of Tautepec is required by them, and removed from it there is no danger of their ever becoming a plague.

Trypeta ludens produced in the City of Mexico from pupæ gathered at Yautepec do not reproduce, nor sting the oranges on which they were confined under mosquito netting. In the warmer and more even climate of Yautepec they are very active, and lay their eggs in the fruit, even in shaded locations.

Upon the action of the State Board of Horticulture prohibiting the entrance of Mexican oranges into California becoming known in Mexico, a strong effort was made to ascertain how widespread the pest was, in order that means might be taken to prevent its spread into new sections, and to extirpate it, if possible, in those parts where it was established. In accordance with this plan the Secretary of the Department of Fomento issued a letter to the governors of the different Mexican States and the agents of the departments, as follows:

It has come to the knowledge of this department that the State Board of Horticulture 
of California has put in operation a measure prohibiting the importation of Mexican oranges into California, under the pretext that the orange worm would spread to the orange orchards of that State.

In order that this department may be in possession of all the facts in the case, and to enable it to take such action as will advance and protect the interests of our agriculturists, I wish you to give us circumstantial information as to the actual state of the plague and the possibility of extirpating it.

Mexico, October 21, 1903.

G. Cosio.

In response to this, many of the governors of the different Mexican States instituted inquiries and forwarded their reports, from which we have translated the following extracts. In addition, the agents of the Commission of Parasitologia were also instructed to make special reports on the orange plague in the various districts. How far these reports are absolutely accurate we are unable to state, as the investigations in many cases were made by untrained and unscientific men, interested in making the best report possible, but it is probable that most of them are correct, inasmuch as it was to the interest of the Mexican Government to secure true reports, in view of their efforts to control the pest.

\section{Aguascalientes.}

I have the honor to reply to your favor of December 16, and would state that the plague commonly known as the orange worm is not known in this State, nor is there any other which is prejudicial to the orange.

Alejandro Vazquez de Mercado.

Chihuahua.

Replying to your inquiry as to whether the orange worm is found in this State, I would reply that our oranges are not affected, but, on the contrary, are of good quality and sent into the market free from the pest.

\section{Coahuila.}

Enrique Creel.

Replying to your favor of the 15 th, requesting information in regard to the orange, I would say that the orange is not cultivated in this part of the Federation.

\section{Colima.}

Miguel Cardenas.

Colma, December 20, 1904.-1 have the honor to inform you that the orange worm has not yet appeared in this State.

\section{Jalisco.}

E. O. DE LA MADRID.

Replying to yours of the 14th of May, 1902, I would state that the orange plague does not exist in this State.

A. E. Romero.

LA BARCA, May 16, 1902.-This office has information to the effect that the oranges in this region are entirely free from the plague, and for the encouragement of the growers in this locality and the interests of the Republic in general, we have requested the following large growers to furnish you with proofs of this statement: C. C. Rives Bros. and Mignel Flores.

L. IGUEZ DE LA TORRE.

Answering your inquiry of the 15th of May, 1902, I take pleasure in informing you that in the whole State the orange worm pest does not exist.

Aurelio de Martinez.

GUADALAJARA, January 30, 1905. -1 have the honor to inform you that the district under my comnand is confined to the municipality of Tizapan el Alto. Orange orchards are found here, and I have communicated the contents of your letter relative 
to the orange maggot to the owners, and they inform me that the Trypeta ludens has never been found in this locality.

\section{Michoacan.}

II. Ahumada.

Replying to your note of December 15,1904 , I would state that this Government has no knowledge of the existence of the Trypeta ludens. However, for further information we have referred your communication to the section in which the orange is cnltivated.

\section{Nuevo Leon.}

Louts DE BALdez.

MonTEREY, January 11, 1905.-Your'letter requesting information as to the 7 rypeta ludens in this State was referred to Manuel G. Rivero, J. A. Robertson, and Arnulfo Berlanga, the principal orange-growers of this section, with the request that they supply the required information. Answers have been received from them, which, by order of the Governor, I respectfully send you, and from which you will see that there are no orange worms found in this State.

Ramon Chavarri.

After a very careful inspection of this district I have found it impossible to discover any indication of the existence of the Trypeta ludens here. I made careful inquiries of some of the oldest orange-producers, and none of them have ever known of the existence of the plague. During my ten years' residence here, during which time $\mathrm{I}$ have occupied myself in orange culture, I have never seen a worm. I have read full descriptions of this pest, and have seen it illustrated in the agricultural bulletins of the U. S. Department of Agriculture and in those from California. I am acquainted with its history and am prepared to find it, but I can positively assure you it has never made its appearance here. I have seen it in oranges from the States of Tamaulipas, Vera Cruz, and Morelos. I have visited the orange-producing States of Sonora and Jalisco, and in neither of these States have seen any indications of the Trypeta ludens. As this pest is one of the most dangerous which may affect an orange district, I hope it may never be permitted entrance there, for that State is the producer of the finest oranges in the world, and is naturally more free than any other section from all orange plagues.

L. N. Stuart, Administrator.

San Luis Potosi.

From investigations carefully made in the districts under my care, I would report that up to date there have been no orange worms reported in this State.

Sonora.

F. Mexpez.

Replying to your favor of the 8th inst., in which you state to the Governor that on account of the prohibition of the Mexican orange in the State of California, you will visit the orchards of Sonora with an entomologist, named by the Horticultural Board of California, I would say that I wish, in order to avoid an unfavorable report, the First Magistrate would order the perfect cleaning of all orchards and secure the action of the Governor in the matter. I would also ask for a list of all the important orchardists, with an estimate of their annual output; also further information as to insects detrimental to oranges.

Conformable to the requests made in your note, it is orlered that ail orchardists, without loss of time, proceed to put their orchards in such shape as to show them in their best shape to the commission which will visit them next February. At the same time the information and statistics which you desire are being prepared,-as to the best orchards in this State, their importance and approximate output.

Relative to the opinion of the government of this State regarding the California prohibition of Mexican oranges, I have the honor to inform you that it is a tariff war against this fruit, which ripens at the same time as that of California and Florida. Therefore, orange-producers in these States, in order to prevent competition with the Sonora orange, have obtained from the American Government a duty, excessively high, which makes the exportation of the Mexican orange to the United States impossible. The problem thus presents two phases to the orchardist of Sonora: First, to find a market elsewhere than in the United States, or to endeavor to protuce an orange 
earlier than those of Florida and California, similar to that produced in Jalisco, which is sold in the American market when there is no California fruit. The demand at the same time increases the price to such a figure as to enable the grower to pay the increased duties and freight.

Our orange-growers are already beginning to export their fruit to the Canadian market, and there is good reason for hoping that we shall build up a larger demand for Sonora oranges in that section.

With regard to getting into the American market ahead of California and Florida, I would state that growers in the vicinity of Hermosillo and elsewhere are now experimenting to produce an earlier orange.

With regard to tise orange worm, it is a satisfaction to me to assure you that we do not have it in this State, and therefore property owners who are growing oranges do not fear any inspection on that account.

Alberto Chubillas.

Hermosillo, December, 1904.-Referring to your note of the 14th inst., I have the honor to inform you that the orange plague is not known in this State.

Tlaxacala.

RAPHAEL IzABAL.

Traxacaca, December 16, 1904.-Replying to your favor of the 14th inst., I would state that the orange is not grown in this State, as the climate is not suitable for it.

\section{Zacatecas.}

ManUel Loaiza.

ZACATECAs, January, 1905.-Replying to your favor of the 14 th inst., I would state that in portions of Fresnillo, Juchipila, Jerez, Nochistlan, and Tlaltenango the orange is cultivated to a small extent, but is not exported to the United States as the crop is not sufficiently abundant, and I would also state that the orange plague is not known in this section.

\section{Eduardo F. Parkhurst.}

\section{REPORTS FROM SPECIAL AGENTS.}

AuthaND, May 23, 1902.-Replying to your request of the 20th inst., I am pleased to inform you that in the canton under my command there is not now nor ever has been an orange worm.

\section{Gonzales Rubio.}

GUARAchita (Michoacan), March 25, 1902.-Almost all the guavas which ripen from July to September, and also the plums, are wormy. This is not the case when they are gathered in March and April. At this period the guavas and other fruit are clean.

E. Aroeo.

Rio VERde (San Luis Potosi), January 12, 1905.-Answering yours of the 13th of December, I will state that in this zone we are entirely free from the plague.

R. T. Y ANEZ.

GuANAJUATo, December 23, 1904.-The Trypeta ludens was found here in only one garden. It was vigorously combatted, was not given time to multiply, and was destroyed. Since then I believe no other flies have been found. If the Trypeta is seen later, I will notify you.

DR. A. Duges.

\section{CONTROL, REMEDIES, AND PREVENTIVES.}

Among the various expedients tried, the following have been found successful as a check:

Incineration. In the worst infested orchards all fruit likely to harbor the fly is carefully gathered, including all oranges, mangoes, and guavas. Large furnaces have been erected in the district and all this fruit, with its contained pests, is destroyed by fire. So thoroughly had this work been done that at the time of my visit it was difficult to find 


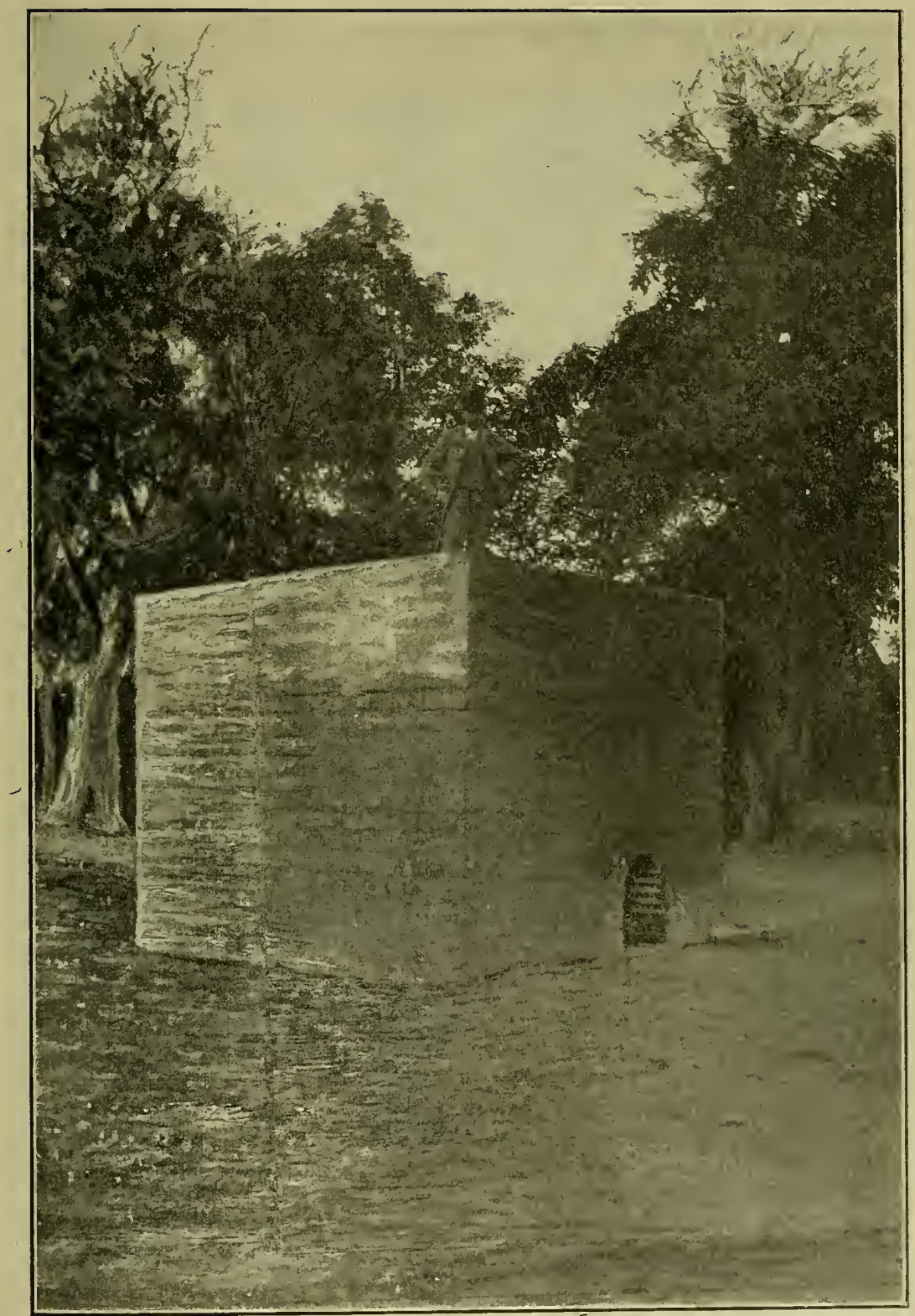

PLATE IV.

Incinerating Furnace at Yautepec, Iforelos, used for destroying wormy fruit. 
any ripe fruit in the orchards of Yautepec. The incinerating furnaces are of rather large proportions, being about eight feet square and of an equal height. The bottom is arranged with a grate, under which the fire is built, and the heat soon reduces the fruit and worms to a harmless pile of ashes.

Burial. Another method of destroying the worms which might have existed in the fruit was by burial. In some orchards great pits had been dug and the fruit was deposited in these and covered with at least two feet of soil, care being taken that it was buried deeply enough to prevent any larvæ which might have matured and worked their way out of the fruit after burial from coming to the surface. I had one of these pits opened and found its contents a mass of rotten pulp, in which most careful search failed to disclose any worms. All worms which had been present when the fruit was interred were reduced with the fruit itself to a homogeneous mass, in which there was no sign of life.

These are the two methods of disposing of the pest in its larval stage, and certainly both are very effective, as there is no possibility of the worm, if it exists in the fruit, escaping in either case. If any of the worms should escape and pass into the pupal stage, another method is resorted to to prevent them from attaining the mature or fly state, and that is

Hand-picking. A large force of peons has been kept at work in all the orchards at Yautepec, whose duty it has been to carefully rake over the soil under the trees in sections known to be infested, and to search carefully through the soil so exposed for any pupæ that may be turned up. This is a somewhat tedious process, but has proved a very effective one, as large quantities of the pupæ have been gathered and destroyed in this manner and the fly crop largely curtailed by this means. After leaving the fruit, when it has attained its growth, the maggot burrows one and a half or two inches under ground to pass through its metamorphosis, and always in the soil under the tree in the fruit of which it has passed its larval stage. By carefully raking this soil over and closely inspecting it the greater part of the pupæ can be discovered and few will escape.

Fowls in the 0rchard. Should any pupa escape in the search, an effort is made to complete the work, and fowls are used as a supplemental agency in the process of extirpation. Movable coops have been arranged and these, each with a number of chickens, are moved about the infested section and the soil beneath the trees is kept constantly raked over and exposed and the chickens find any of the pupæ which may have been overlooked. 
Insecticides. The warfare on the Trypeta ludens has not, however, been confined to the insect in its larval and pupal stages. It has been determined that no fly shall escape if the Commission of Parasitologia

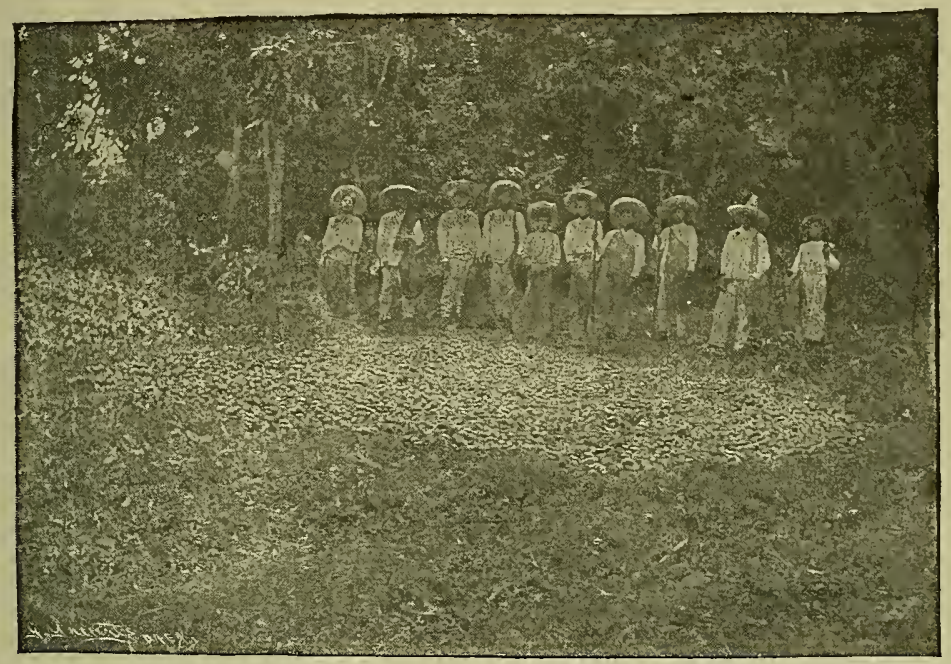

Force of laborers employed in gathering infested fruit.

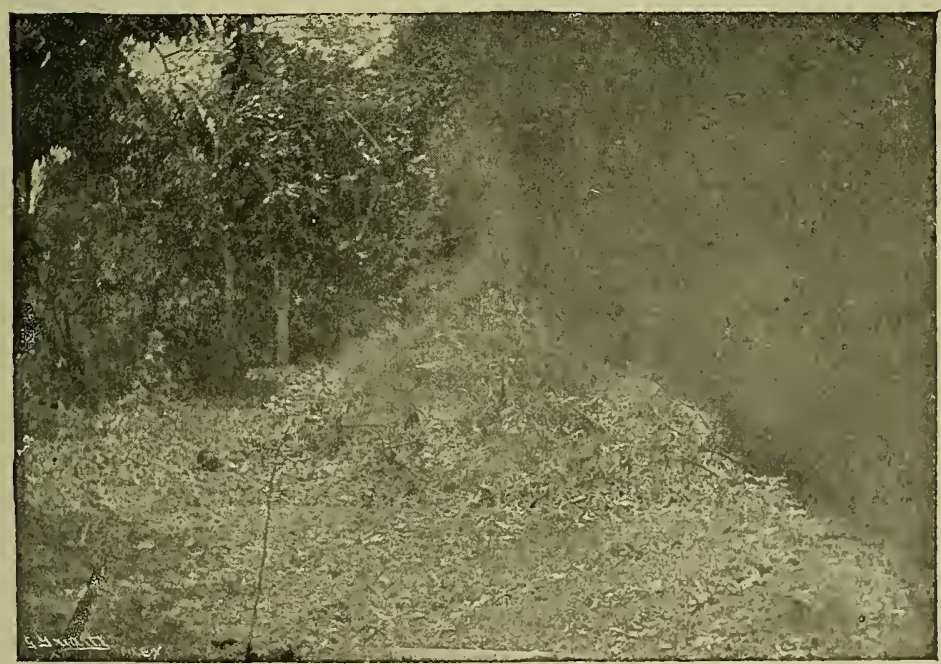

Destruction of infested fruit by fire.

PLAte V. Destroying Infested Fruit at Morelos.

can compass its destruction. In the course of many experiments looking to the control of the Trypeta ludens, Mr. Don José Betanzos discovered the usefulness of a common Mexican plant for this purpose. 


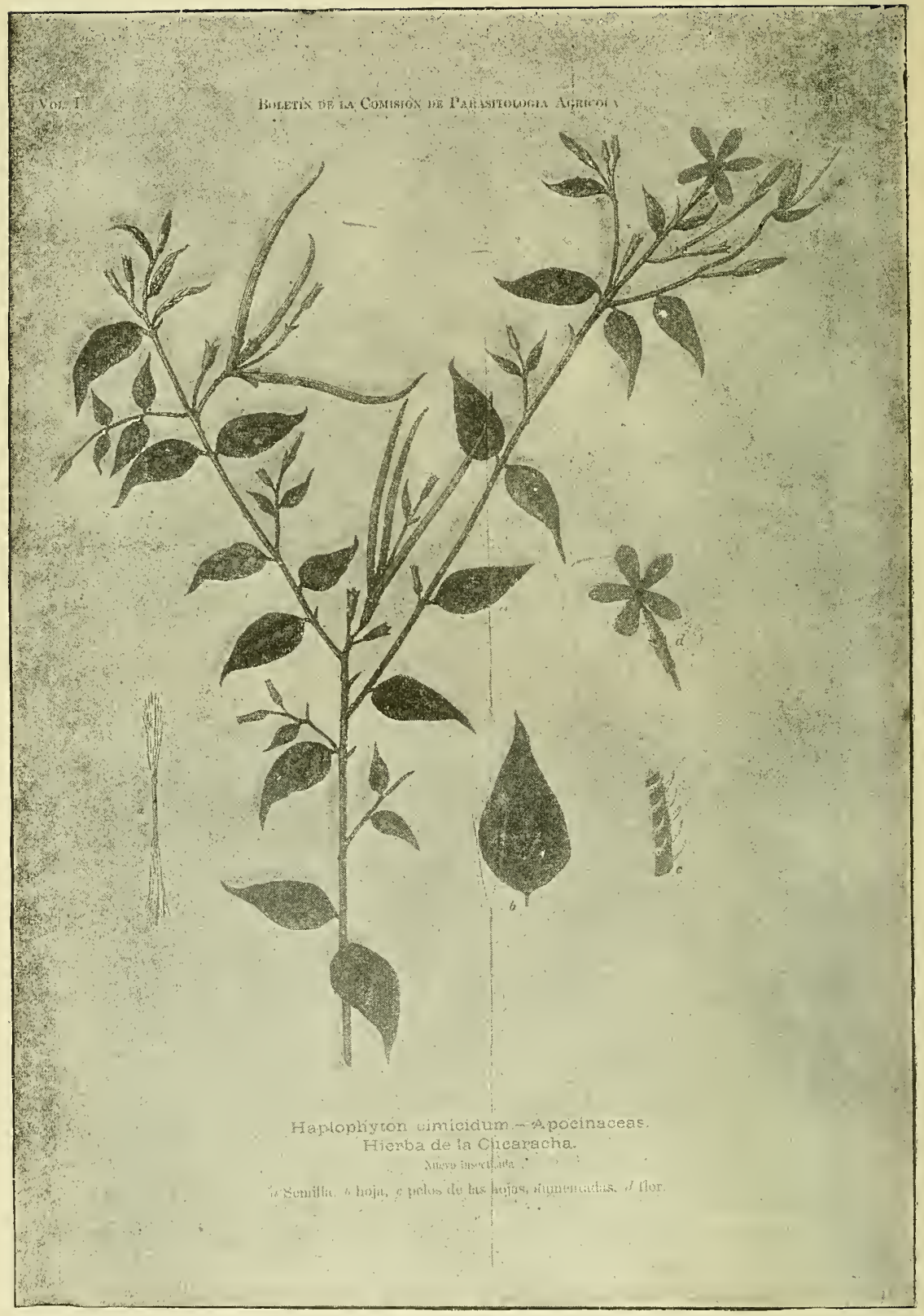

PLATE VI. HAPLOPHXTON CIMICIDUM.

Plant used for poisoning flies of Trypeta ludens.

(From the Commission of Parasitologia.) 



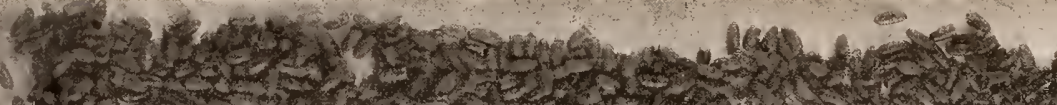

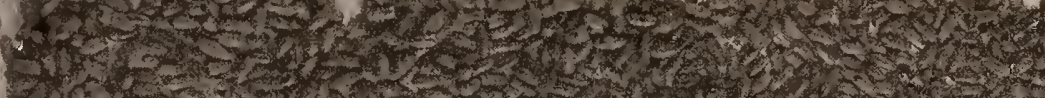

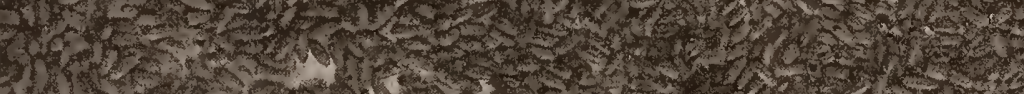

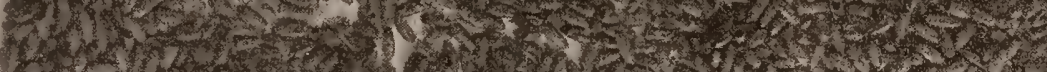

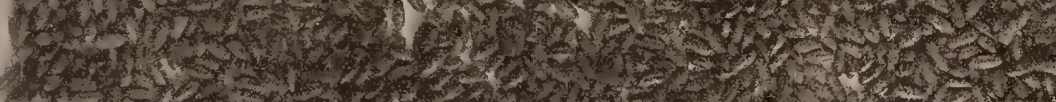
1.t.

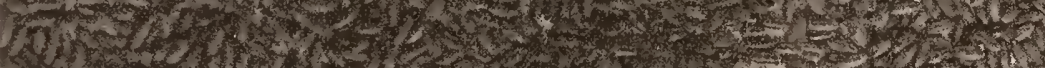

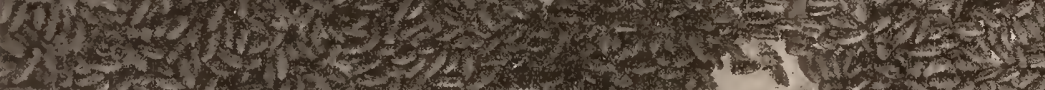

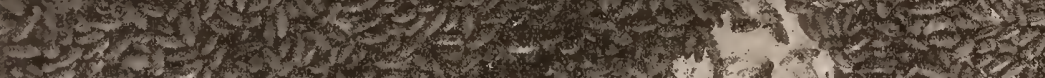

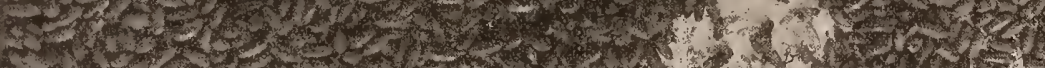

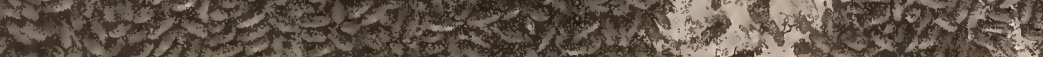

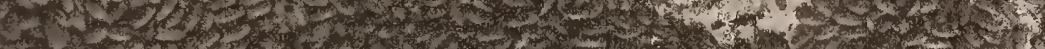

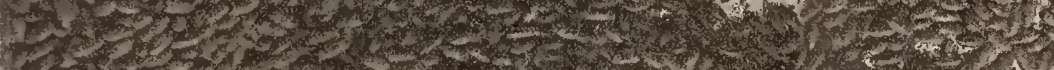

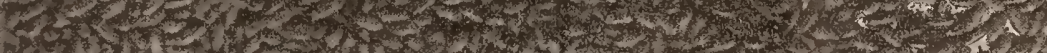

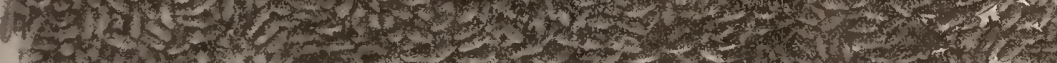

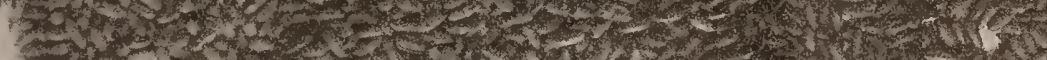

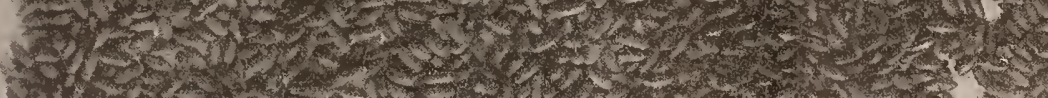

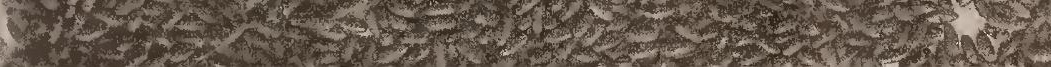






\section{CRATOSPILA RUDIBUNDA}

\section{(PARASITE OF THE ORANGE MAGGOT}

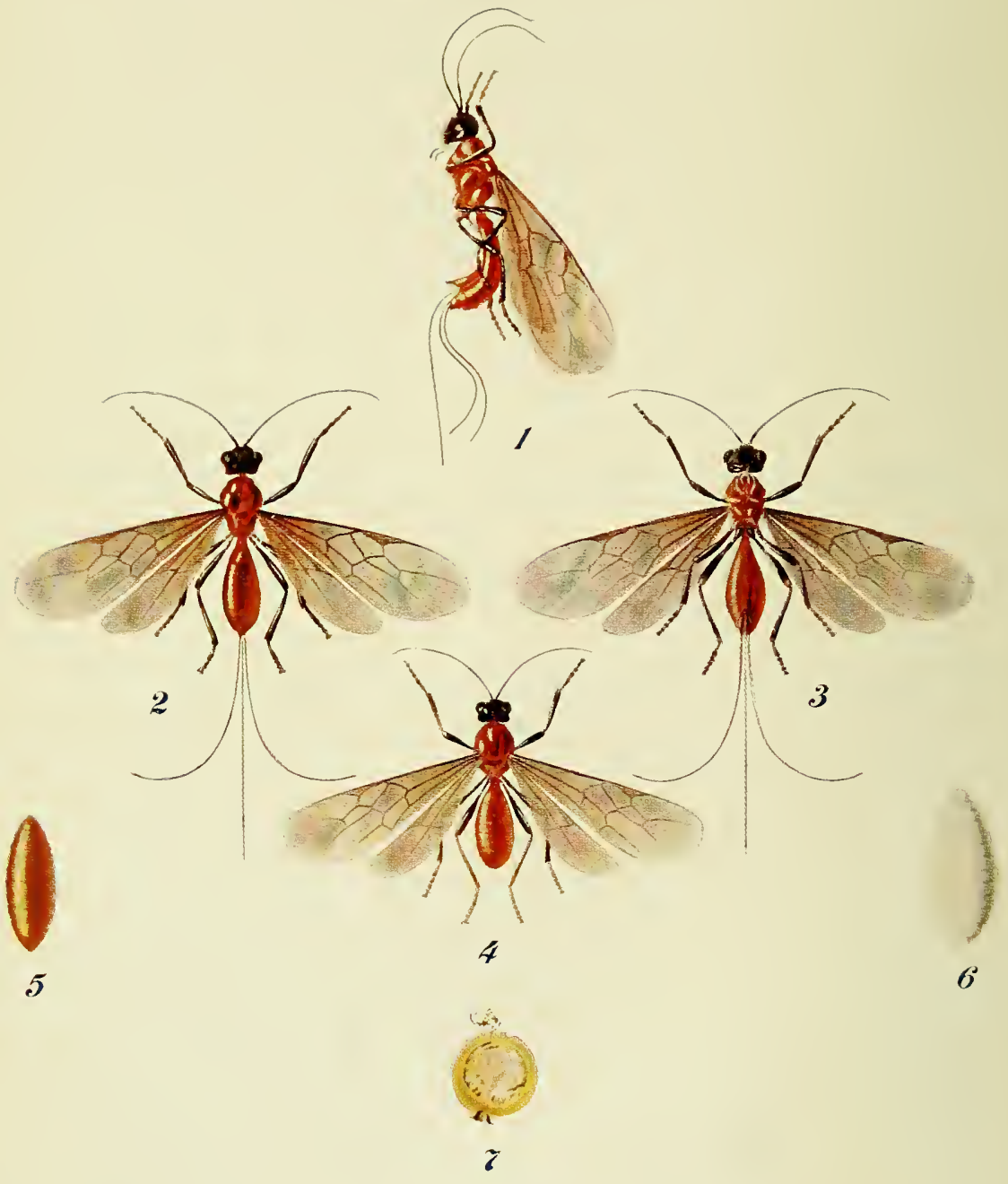

From Drawing by the Comision de Parasitologia Agricola, Mexico. 


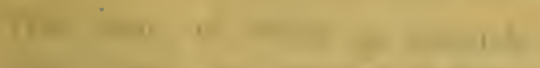

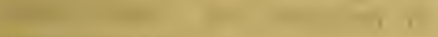

1 1

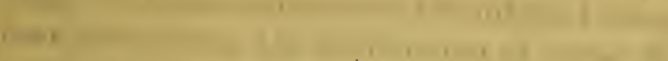

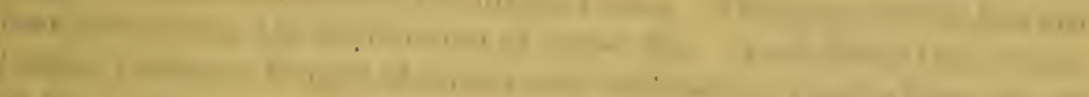

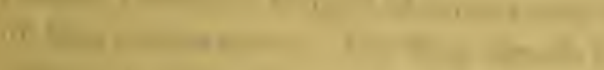

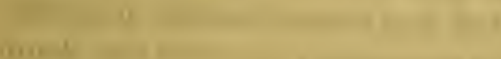

1

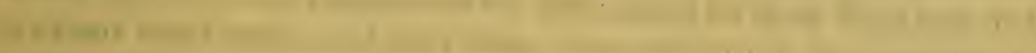

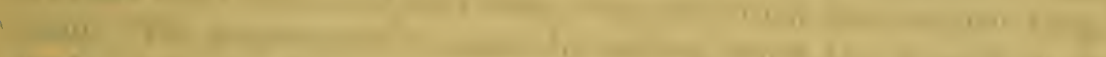

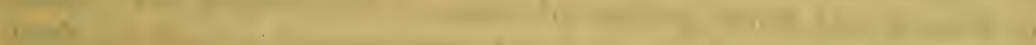

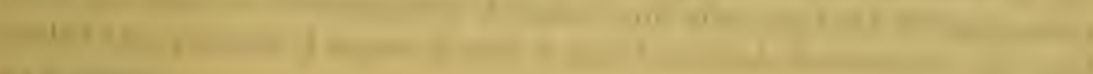
$(4+1)$

\section{Kin $14 \mathrm{~B}$}

1,

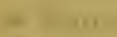

H. 10

-

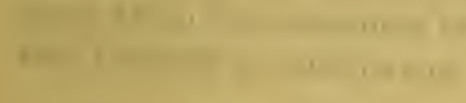

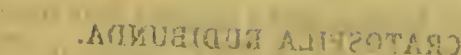

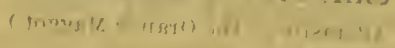

\section{Rowi=}

$1,0 \times 1$
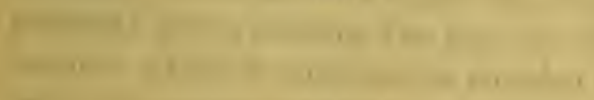

$x+1,0$

(

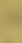

1.

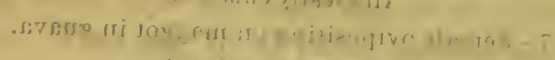

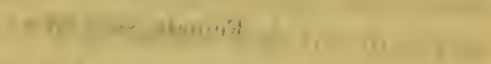 $\therefore x^{5}, 0, \ldots, 0,0,1-1$
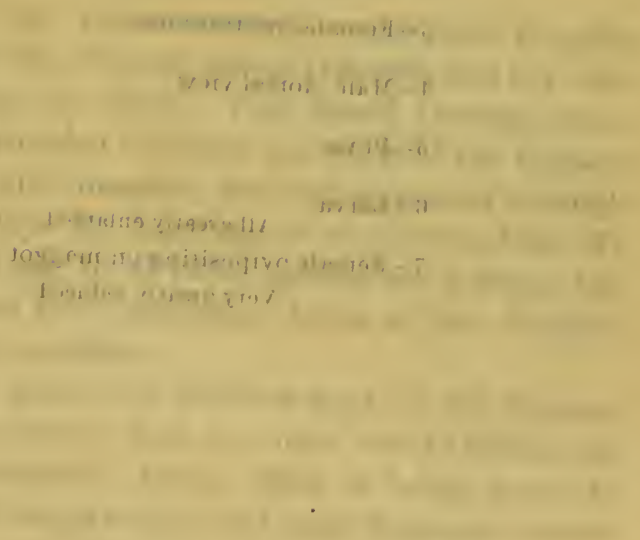

1.

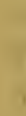

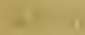

n.

n $n$

, $+1=1$ 


\section{CRATOSPILA RUDIBUNDA.}

(Parasite of the Orange Maggot.)

1-Female, side view.

2-Female, dorsal view.

3-Female, ventral view.

4-Male, dorsal view.

5-Pupa.

6-Larva.

All greatly enlarged.

7 -Female ovipositing on maggot in guava.

Very greatly reduced. 
This plant, of which we publish an illustration, is the Haplophyton cimicidum. An infusion of this herb is prepared and sweetened with sugar, and then sprayed on the infested trees. This preparation has also been effective in the destruction of house flies. In fighting the Trypeta ludens, Professor Rangel obtained very satisfactory results from the use of this preparation. The flies absorb the sweetened fluid with avidity, and soon become torpid and fall to the ground. Flies so poisoned are much agitated, rub themselves all over, stand on their hind legs or hang by their front ones until they drop, when they turn over on their backs, dead. The preparation is made by boiling about two pounds of the herb, cut fine, in three gallons of water, and after the herb is thoroughly boiled two pounds of sugar is added, and the whole is strained and used as a spray.

Natural Checks. In Nexico it is claimed that extremes of temperature form one of the most important natural checks on the spread of this insect, and that it can not endure extremes of either heat or cold, a temperature below $37^{\circ}$ or above $100^{\circ}$ Fahrenheit in the shade being fatal to it. We do not know how extensive the observations have been upon which this statement is based, but it is probable that the insect is kept in check to some extent by extremes of temperature.

Parasites. An ichneumon fly, the Cratosipila rudibunda, is quite common in the sections where the Trypeta ludens is found, and is a very material aid in keeping the pest in check. This insect, through some instinct which it possesses, is enabled to locate the worm of the Trypeta below the surface of the fruit, and, inserting its long ovipositor through the outer coating of the fruit, lays its fatal egg in the larva of the fly with unerring accuracy. This egg, in its turn, hatches out a worm, but within the body of its host, and the unfortunate larva of the Trypeta ludens never attains its perfect condition.

The parasite has not as yet done very effective work on the Trypeta ludens, as investigations have shown that not over ten to fifteen per cent of the maggots are parasitized. Every effort is being made to encourage the propagation of the parasite, and great hopes are entertained that it may yet overtake the plague and keep it in check.

The extent of the work done by these rarious checks is shown in the fact that prior to the active work undertaken by the Commission of Parasitologia the markets of the City of Mexico and of the northern Mexican States were flooded with wormy oranges in November to January, and this was so noticeable to visiting Americans that many of them forbore to use the fruit for fear of the pest; while inquiry among the same class and among fruit merchants of the City of Mexico elicited the information that during the past season there was a notice-

3 - TL 
able diminution of wormy fruit on the market, and in fact little of it has been noticed. People of whom I made inquiries relative to the prevalence of the pest did not know any reason for its decrease, and were satisfied to state that the oranges during the past two seasons were not so wormy as they used to be. Whether the efforts of the Mexican Government can reduce this pest below the danger limit is an open question, but it is certain that no effort on its part is being spared to do so.

While strong efforts have been made in all those sections of Mexico where the worm exists to get it under control, the principal work has been done at Yautepec as the center of infestation. Here every experiment looking to the extirpation of the pest has been tried, and the Government has used coercive measures where necessary to compel fruit-growers to follow the plans outlined for them by the Commission of Parasitologia.

As indicating the method pursued in fighting this plague by the Nexican Government, Professor Herrera reports the destruction of fruit at Yautepec, in the State of Morelos, for the past three months, as follows: March 10th, 10,101 oranges; March 18th, 10,327 oranges. The number of mangoes destroyed by fire was, March 25th, 6,137; April 1st, 3,095; April 5th, 14,986; April 13th, 18,942; May 20th, 17,612; May 27 th, 40,093; June 3d, 39,218. This was all fruit growing in the infested district which was destroyed in order to reach the enclosed larvæ.

It is probable that the Trypeta ludens is, as stated by the entomologists of Mexico, an imported pest; that its country of origin is some part of South America; and that, as its food plants have spread along the tropical sections of Mexico, it has gradually followed until it has become established in tropical Mexico. If this is the case, it is quite probable that its natural enemy will yet be found in South America, and a more efficient check be obtained for it than now exists. This supposition is largely borne out by the fact that Mr. George Compere, after searching over a large part of the world to discover the original home of the Australian fruit fly, discovered it in Brazil, and there found its parasite. It would appear quite likely, therefore, that the Trypeta ludens may have originated in the same life zone with its Australian relative, and that the natural enemy of both may exist in the same section.

The most efficacious method of controlling this pest, so far, is thorough cleanliness in the orchard, and the destruction, by burning or burying, of all infested fruit before the larve leave it for the purpose of pupation in the earth. Other methods have been found either impracticable or too expensive in large orchards where generations of flies are bred in different fruits and during the whole year.

An inspection of the orchards of Yautepec, made in February, 1900, 
convinced the Commission of Parasitologia that the best method of controlling the pest would be the total destruction of all kinds of fruit, green and ripe, wild and cultivated. Early oranges appear in Yautepec in January to April or Nay. This crop of fruit, if destroyed by fire, would cut the cycle of the generations, and the flies produced from the pupæ in the soil would find no fruit upon which to oviposit, as the mango ripens only in July. This process, to be effective, according to Professor Herrera, should be general in all southern Mexico, where the plagne is known to exist; for if the work is confined to one section, even if ever so thoroughly performed, the insect may be reintroduced from other infested regions. So the plague should be attacked at the same time in all parts, destroying, if necessary, all oranges and mangoes in the infested sections, in order that there may be no spot from which the plague may be afterwards disseminated.

The spread of the pest may be prevented by the gathering of all the green fruit before the female fly has deposited her eggs below the rind. But if this work is not generally done, enough of the flies will escape to give the plague a new start. The guava is a fruit within which the fly is generally found, and as this grows wild in many places, it would be necessary to destroy this also.

The pest is bred in and spreads from the fruit which falls on the ground and which is allowed to remain there, and while this is left undisturbed, neither reduction of transportation rates nor a lower tariff will help the orange-growers. It is all in vain so long as the growers fail to destroy the fruit which falls and which contains the worm. Even with the destruction of the fallen fruit there is danger that some of the larvæ may leave the fruit still on the tree, and, by reaching the ground, find a place of safety for their transformation. This last contingency is being made a matter of special study by the commission and its agents, and various methods of reaching the pests have been tried.

\section{HABITS.}

(Translated from bulletin of the Commission of Parasitologia.)

The Trypeta ludens attacks the sweet orange (Citrus aurantium), mango (Mangifera indica), and the guava (Psidium pomeriferum). Worms in mangoes, which we had under observation in April, and which were secured in Cuernavaca, transformed into pupæ, and in thirty-seven days developed into flies, exactly as did those of the orange. One larva passed through its changes without learing the fruit, while another transformed on the surface without entering the soil.

The worms are very voracious, and in a short time will devour a mango or a section of an orange. They are sometimes found in numbers six to eight, nine to ten, or even as many as twenty-four in one fruit, the average number being five. It is a provision of nature that 
the female fly is provided with an instinct which prevents her from laying over six to ten eggs in one place, for if she deposited all her seventy or more eggs on one fruit, there would be insufficient food for the worms. The eggs are laid in clusters, and the female deposits them on eight or ten or sometimes more specimens, so that one female fly may infest a number of individual fruits.

The orange worm, like most of those living in liquids, is very hardy and withstood for some time immersion in dilute ammonia, acetic acid, and feeble solutions of formalin and alcohol. In passing from a sweet to a sour orange, or from an orange to a mango or guava, the changed conditions did not seem to affect it. Various other experiments-submersion in water, electric shocks, etc.-were tried, but without serious effect to the worm.

[In San Francisco a lot of maggots were taken direct from some oranges imported from Acapulco, and were placed in undiluted alcohol. None of the worms died in less than ten minutes, and some even showed signs of life at the expiration of half an hour. Their natural habitat is immersion in the juices of the half-ripe fruit, and it is undoubtedly this fact which enables them to withstand immersion in stronger fluids for so long a time. The experiment in San Francisco therefore bears out those of the Commission of Parasitologia in Mexico.]

As soon as the worm has attained its growth, it leaves the fruit, which usually falls, and seeks a spot in which to hide away during the period of transformation. In soft soil this is easily done. In some instances they remain between the sections of the orange or within the guava. In cases where the fruit does not fall from the tree, the worms will leave it and drop to the ground, which they penetrate for the purpose of pupation.

The orange is always attacked on the under side, and when the fly is. preparing for oviposition she moves slowly over the fruit as though seeking for an appropriate spot. When this is found she quickly attaches herself in a perpendicular position and remains quiet for a period varying from a few seconds to two minutes. She repeats this operation three or four times, when she flies to another fruit and repeats. the process.

Professor Rangel experimented with twenty Trypetx which he had confined under a mosquito net with some oranges and guavas. One female perforated the rind of the guava; all the others preferred the oranges. One of the latter perforated the same orange four times and another six times, the whole operation requiring half an hour.

The eggs are deposited by the female in the pulp of the fruit at or near the ripening period, and are probably acted upon by the increased temperature characterizing that period. Incubation progresses under favorable conditions of shelter, moisture, and inaccessibility to ichneu- 
mon flies and other parasites, which can not from the outside discover the location of the eggs and are unable to penetrate the epidermis in search of them.

\section{ACTUAL CONDITION OF THE PLAGUE.}

(Translated from bulletin of the Commission of Parasitologia.)

Agents sent to Morelos at the end of July this year (1900) report the fly as very rare, but it still exists, and in Yautepec the first generation which proceeds from the mango is appearing. In Yautepec there are wormy guavas, and Mr. De la Bareda states that on July 23d he visited a district in Cuernavaca, where the guava is abundant, and nearly all the fruit was infested.

Almost all of the larvæ of the fruit which is exported from the State of Morelos perish from one cause or another, or are unable to find suitable conditions under which to pass through their transformation, and the flies are very rarely found in the valley of Mexico. Here is one of the great reasons why the plague is not more serious. Each season, millions of the worms are shipped from Morelos in the fruit, and of all these, few attain maturity and none perpetuate themselves.

On August 10th, Professor Rangel extracted over 4,000 pupæ from the soil by raking it over and hand-picking. This indicates that a new generation of winged insects would soon appear and it is this generation which does the worst work on the oranges.

\section{RULES FOR COMBATING THE PEST.}

The Commission of Parasitologia has formulated the following rules for fighting this pest:

1. Gather each day all mangoes, lemons, and oranges which may have fallen from the trees, and deposit them in a clean corner of the orchard.

2. Destroy all fruit so accumulated at least once a week.

3. It is preferable to destroy the fruit by burning, but it may be disposed of by burial, and when buried it should be covered with at least fifty centimeters (about 20 inches) of soil.

4. As the same worm exists in the guara, this fruit should also be destroyed in the same manner.

\section{COMPETITION WITH MEXICAN ORANGES.}

In a bulletin issued by the Comision de Parasitologia Agricola on the Trypeta ludens, under the heading of "Unjust Prohibition of the Mexican Orange in California," it is stated that, according to circulars published by the Ministry of Fomento, the Board of Horticulture of the State of California has prohibited the importation of Mexican oranges 
under the pretext that it might be the means of introducing this terrible plague into the orchards of that State. The report continues:

It is the opinion of the most distinguished members of the Agricultural Society of Mexico that the California horticulturists have always dreaded competition with our fruit, as our more favorable climate causes our oranges to ripen much earlier than theirs and gives us the advantage in the American market.

Our early exports were treated with discredit, as the fruit had been imperfectly packed by novices, but these faults were soon corrected, and one would have thought that there would have been no more difficulty; but, far from it, they fought tenaciously to impose such high duties as to practically prohibit our orange exports into the United States.

California is not weakening in the crusade she has carried on against the importation of our oranges, and she now accomplishes the desired end by barring the entrance of Mexican fruit into America.

This idea is prevalent among a great many of the Mexican growers, and it is openly expressed, in much of the correspondence and many publications, that jealousy and fear of Mexican competition have been the main causes for the embargo placed by California upon the Mexican fruit. It is asserted that the fruit grown in our sister republic is so superior in quality to that grown in California, that there was even danger of our oranges being crowded out of our own markets, and that to prevent this we had to put an embargo upon the Mexican fruit, using the presence of the worm as a mere pretext for our action. A suspicion of this kind is not creditable to either nation, and it was my effort to remove it by a plain statement of the facts in the case. I assured the Mexican authorities that the only reason for our embargo lay in the fact that we were not prepared to take the chance of introducing into our orange groves a new pest which might prove a very serious one should it become established. When the great importance of our citrus industry is considered; that it is one of the greatest single sources of revenue to our State; that in it are invested millions of dollars of capital; that it gives employment to thousands of people, and that even a small injury inflicted upon so important an industry might mean enormous loss in the gross, it is not necessary for us to seek for an empty pretext to care for it. There is nothing farther from the minds of California growers than jealousy of their Mexican neighbors, nor do they fear anything less than competition from that source.

That Mexico could grow good oranges is unquestioned; but she does not, and it will, under the best conditions, be many years before she can possibly compete with the product of California. In the course of $\mathrm{my}$ investigations I saw some fairly good orchards, but even these would not compare with the average of those in California. As a rule, however, fruit there is grown by accident. The seed is planted and if it grows it is well, equally well if it does not. There are no varieties, for all are seedlings; the trees are neither budded nor grafted and show no indications of the care which is bestowed upon them in our State. 
Usually they grow without any regularity, mixed with mango, coffee, and banana trees, the whole forming a perfect jungle, which would be fatal to any growth in our orchards. Being all seedlings, the fruit

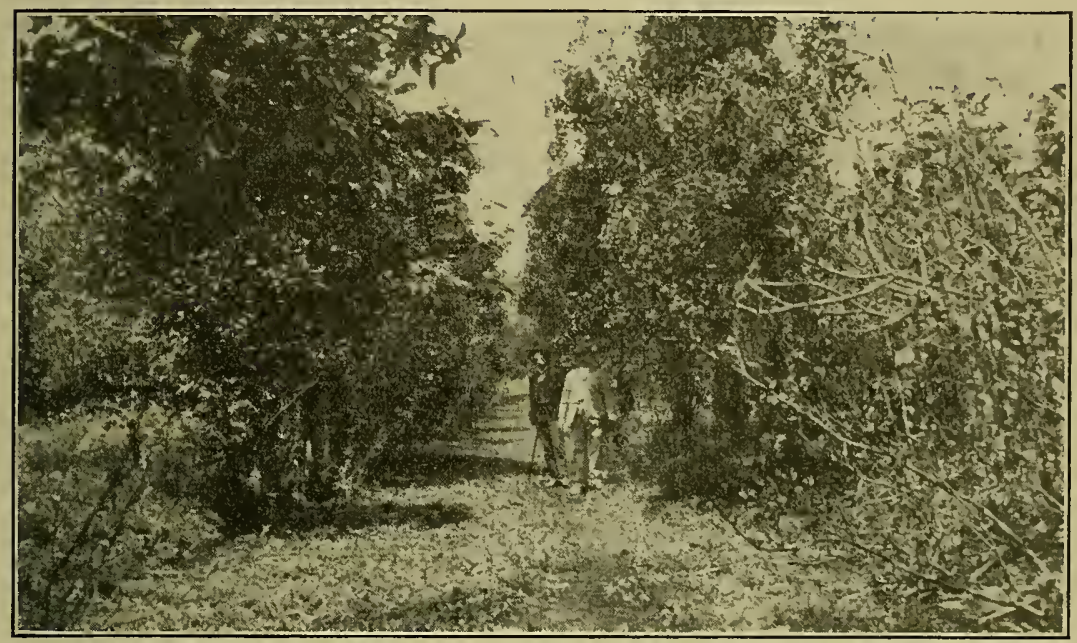

Orchard near Cordova, Vera Cruz.

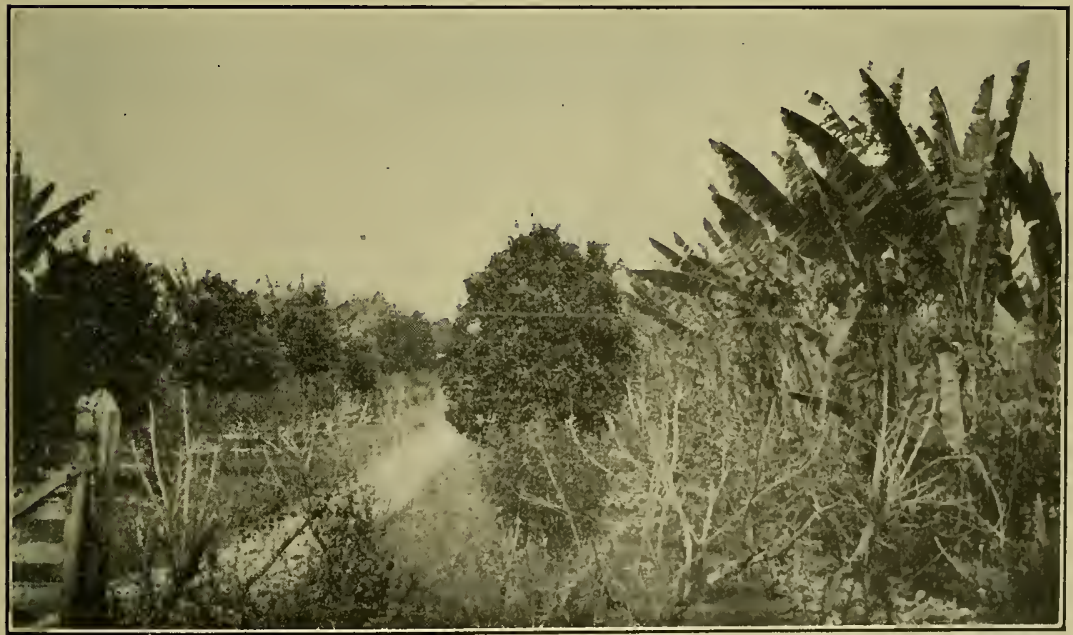

Orchard near Jalapa, Vera Cru\%.

PLATE IX. Mexican Orange Orchards, Showlyg Metion of Cretivatiox.

varies with every tree, and while some of the oranges are of excellent flavor, there is no guarantee that in purchasing fruit you will get two specimens of the same quality. No eare is taken of the orchards, and pruning, cultivating, grading, and other matters which are so carefully 
attended to by us are entirely ignored. In the markets of Mexico I saw oranges brought in carts over the rough roads, shoveled from the carts into baskets, transferred on the backs of peons and dumped in big heaps in the wholesale houses, from which places they were distributed with no more care. In the whole process they are handled as we handle so much coal or gravel. There is no uniformity of color, size, or quality.

There is no doubt that Mexico possesses all the requisites of soil, climate, and natural conditions for producing good oranges, but so long as her growers resort to their present careless or indifferent methods, California orchardists need have no fear of competition from that source, and the statement made that we have used the presence of the Trypeta ludens as a mere pretext to prevent the superior Mexican fruit from driving ours from the market will strike our growers as puerile.

The total production of citrus fruits in our State is now from 25,000 to 30,000 carloads annually. The fruit is carefully grown, picked with the greatest care, and handled at all points as tenderly as so many eggs. It is assorted and graded, carefully wrapped, and put up in such a way as to reach the markets in the most attractive shape and best possible condition, and were the markets of the United States thrown wide open there would be no chance for the Mexican fruit, grown and handled as it is now, to compete with that of California.

The statement that oranges there come into the market before those of California also arises from a misunderstanding of conditions here. The orange season in California is continuous. There is no month in the year when we can not ship oranges, and when we do not ship them to the Eastern markets. The great bulk of our crop is shipped in the late winter and early spring months, as the demand is more active at that season.

The fear of the introduction of the Trypeta ludens has not been a mere pretext, therefore, to avoid competition with a formidable adversary, but a dread of a genuine danger which we believed threatened one of the great industries of our State. This fact, I believe, has now been made clear to the officials of our sister republic, although they still regard our fears as somewhat exaggerated.

That the Trypeta ludens is a serious pest in the sections where it is established is acknowledged by the Mexican authorities, and they are using every possible means to check its spread and also to extirpate it.

The belief that our action against Mexican oranges is due to jealousy and fear of competition is an unfortunate one. It is based on ignorance of true conditions, and a broader knowledge of the California orange industry will remove it. The Mexican Government respects the precautions which we have taken for the protection of our fruit, and realizes 
the fact that they are not prompted by petty motives. At the same time there is a prevalent fear that the California embargo may become general and that the Mexican fruit will be prevented from entering the United States. To remove any possible cause for such embargo the Mexican Government has left no stone unturned, and no expedient which would keep the orange pest in check has been left untried. If the pest can not be exterminated it will at least be kept in check and any danger from its introduction be reduced to a minimum.

As indicating the sentiment of Mexican growers and Mexican journals, we translate the following:

"El Agricola" publishes the following under the heading "The Mexican Orange":

The embargo placed upon the importation of Mexican oranges is a hard blow at one of the most important of our products. The motive that California alleges is that worms in our oranges might propagate and invade their orchards and scriously interfere with their great production of fruit.

This movement may at first appear to be justified, but if we consider the strong opposition whieh California has made to onr oranges from the first day of our appearance in their market, it is easy to understand that there is another reason for the American producers to maintain the prohibition.

Although our first fruit exportations were small, they were sufficient to prove to our neighbors that Mexico, with her incomparable climate, and enjoying an era of prosperity and peace, would soon become an important factor in the world's market with the products of her soil; that this humble beginning in the shipment of oranges would, in a short time, increase to great proportions, and as they could defy commercial competition with the whole world, they feared that our fruit, which a more propitious climate ripens a few months sooner, would be the earliest in the market. In the beginning they regarded our shipments as trifling, and, owing to poor packing, as unworthy of consideration, but we promptly corrected this error and hoped that there would be no more difficulty. Far from leaving us in peace, however, California insisted that high duties be imposed upon the Mexican fruit, and this was practically equivalent to an embargo placed upon all our fruits in the American market. We do not deny the existence of wormy oranges in Mexico, but these are found only in the State of Morelos, and it seems that a resolution which so seriously injures us should have been linited in its execution to the infested district. We suppose that the Americans, so much ahead in everything, have means of recognizing the damaged oranges from the others, so that they could destroy the bad and admit the others.

To avoid this danger we should take some measures, upon which we shall speak more fully in another issue.

The following appeared in "El Progreso de Mexico" under the heading of "Exportation of Mexican Oranges":

We read in one of the city papers: "The Mexican orange has obtained the preference over that of California. This orange has been exported principally from the frontier, but the railroad from Cuernavaca unites Morelos with the nation's capital, and thus the fruit may easily be sold in the great centers."

It is lamentable that some of our contemporaries are sprealing errors like that contained in the above. It is false that the United States prefer our oranges to theirs. The fact is they only purchase ours when they are unable to get those of their own growing. We should not forget that the American orange is actually superior to ours. We say this because we can, with proper care, produce as good, or better, oranges than those of either California or Floricla. The first great requisite for an agriculturist as well as for a mechanic is to know exactly the qualities and defects of his products. It is the only 
way to become superior to his competitors. It is better, in the present case, to frankly confess that we are inferior to the American orange-growers, and then take all ineasures to change this state of things.

In regard to the oranges produced in the State of Morelos we have said a hundred times, and everybody knows it, that they are wormy. They know this in the United States. The California producers, who appreciate the strong competition which we may maintain with them, do not hesitate to make this known. The day that a carload of Mexican oranges arrives in the United States, it will be detained at the border and probably destroyed. The California horticulturists will then repeat their song, "All Mexican oranges are wormy." The exportation of oranges from Morelos is practically impossible. It will do no good to the producers of that State, and will cause prejudice to the other productive regions of the Republic.

The bulletin of the Agricultural Society of Mexico, October 17, 1900, has the following to say regarding the orange worm and its work:

For some time past attempts have been made, under various pretexts, to exclude Mexican oranges from American markets, the orchardists of California objecting to. competition with our fruit.

The strongest reason so far advanced for this course is that there is a worm in our fruit, and that it might affect their oranges. Since the embargo which was placed upon Mexican oranges by California went into effect, our Government has taken a great deal of pains to ascertain the extent and amount of damage done by the orange worm in the Republic of Mexico. From its investigations it appears that the worms which the Californians dread so much are only found in the State of Morelos, and that there is. no reason for the prohibiting of Mexican oranges whatever. Our Government has taken various measures to combat the plague, and experimented with various processes. It has ordered the destruction of all infested fruit, and recommended the greatest cleanliness in the orchards in orler to prevent the reproduction of the pest. Through these experiments on the part of the Department of Parasitologia, the important fact has been established that the worm which attacks the guava, and is found in Jalapa, Coatepec, and other places, is all of the same species, and if the orchards are kept clean the worms will not attack the fruit. This should be a strong argument to prove that California need not apprehend the introduction of this pest, as their orchards are always kept very clean.

The bulletin of the Agricultural Society of Mexico of the 30th of November, 1896, published the following from the International Bureau of Information at El Paso:

Commercial circulars here incline to the belief that Mexico is designed to become a formidable competitor of California, Florida, and Italy as a producer of oranges. The Mexican grower can now export his products with facility, thanks to the railroads which unite this country with the United States. Land in Mexico is cheaper, as also is labor, and Mexico can produce oranges enough to supply American markets and realize good profits even though selling them at lower prices than those of California and Florida.

\section{A bulletin of the Agricultural Society of Mexico, dated June 30, 1897,} has the following in regard to Mexican oranges:

From early days in their histories, New York, Philadelphia, Boston, and other prominent cities of the United States have been inporting large quantities of oranges from Central America, the Antilles, Italy, and Valencia. The railroads connecting the United States with Mexico were not finished when, in 1880 and 1882, some enterprising individuals with a little capital endeavored to introduce oranges from Mexico direct to the United States. At the present time the exportation is considerable. The fruit reaches the United States through El Paso, Nogales, and Laredo, and so favorably has onr 
fruit been received that in many markets of the United States it has entirely supplanted not only the foreign, but also fruit from California and Florida. The very name of Mexican oranges became a guarantee of their quality, and so favorably were they known that peddlers cried them as "sweet Mexican oranges." From these facts it is not surprising that orange culture in Mexico has received a great deal of attention among the agriculturists, which is only equaled by that of coffee culture. The production of oranges at the present time is insufficient to supply the demand, as may be seen from the following table* showing the quantity produced, together with the value in Mexican coin, in each State and Territory of the Republic:

\begin{tabular}{|c|c|c|}
\hline $\begin{array}{l}\text { State. } \\
\text { Aguascalientes } \ldots \ldots \ldots\end{array}$ & $\begin{array}{l}\text { Number. } \\
178,000\end{array}$ & $\begin{array}{r}\text { Value. } \\
\$ 850\end{array}$ \\
\hline Campeachy -............... & 158,000 & 136 \\
\hline Colima & $4,418,000$ & 5,830 \\
\hline Chiapas_-.....-. & $4,737,000$ & 10,345 \\
\hline Chihuahua ..... & 694,000 & 6,580 \\
\hline Durango......... & $3,396,000$ & 15,950 \\
\hline Guanajuato..... & $1,051,000$ & 3,727 \\
\hline Guerrero........ & 814,000 & 2,344 \\
\hline Hidalgo ......... & 179,000 & 408 \\
\hline Jalisco & $14,951,000$ & 145,100 \\
\hline Michoacan ....... & $25,020,000$ & 93,668 \\
\hline Morelos & $5,160,000$ & 42,134 \\
\hline Nuevo Leon & $13,820,000$ & 62,030 \\
\hline Oaxaca & $13,110,000$ & 43,786 \\
\hline Puebla. & $6,133,000$ & 2,455 \\
\hline San Luis Potosi & $33,270,000$ & 110,562 \\
\hline ( & $3,327,000$ & 23,020 \\
\hline 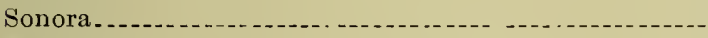 & $28,625,000$ & 241,425 \\
\hline (1) & 446,000 & 998 \\
\hline pas & $4,150,000$ & 7,350 \\
\hline orio de la Baja California & $3,852,000$ & 12,740 \\
\hline - & 650,000 & 2,583 \\
\hline Vera Cruz & $4,125,000$ & 13,996 \\
\hline
\end{tabular}

The data of this table are not all correct, but give a general idea of the importance which the production of this fruit has acquired. The State of Vera Cruz, for instance, produces a greater quantity than either Morelos or Puebla. This production will certainly increase and in a few years will exceed that of California, which has created so many fortunes. This year (1897) oranges have been sold in Yautepec from $\$ 6$ to $\$ 8.75$ per thousand; in La Barca, in the State of Guadalajara, from $\$ 10$ to $\$ 15$; in Hermosillo, from $\$ 10$ to $\$ 20$. To estimate the profit of this business, it may be stated that in Chicago, Kansas City, St. Louis, and Cincinnati, Mexican oranges are sold from 50 cents to $\$ 3.50$ (American gold) per box, which contains from 176 to 200 oranges. These having been bought in Mexico for from $\$ 6$ to $\$ 8$ per thousand (Mexican money), it is easy to estimate the profit in the business, as the packing and shipping expense is trifling. When the producers market their own fruit instead of selling it to outside dealers who are now appropriating the greatest profits, this branch of fruit-growing will prove very profitable.

* The figures given in the above table represent the number of oranges produced, as oranges are sold by the thousand, and the value is in Mexican money, which represents one-half the value in American coin. Fruit conditions in Mexico are practically the same at present as when this was published. 


\section{CORRESPONDENCE.}

The following correspondence passed between the members of the commission for the investigation of the Trypeta ludens, and formed part of the report made to his government by Professor Herrera:

\section{Mexico Citr, March 25, 1905. \\ J. Isanc, Esq., Delegate of the Commission of Horticulture for the Study of the Orange Plague-Present:}

DEAR SIR: Wishing to present to the Department of Fomento the following report, I beg to be allowed to submit to you some questions and to consult you on some points still doubtful and relative to our commission, in the hope that, if not inconvenient, you will kindly answer me in writing, so that I may have a clear and exact knowledge of your valuable opinion and thus be able to present it to the Department of Fomento.

First-I wish to know whether you desire to visit any or all the places of the Mexican Republic where the orange is grown, besides those you have already seen, in order to get at once the necessary transportation on the railroads, and also that I can prepare everything that may be convenient to be able to accompany you, without any restriction whatever as to the places, climates, or duration of the explorations. In fact, I wish you to be perfectly satisfied in every point, and I shall be very much pleased to have the honor of accompanying you and thus enjoy your instructive and worthy society and profit thereby.

Second-I give you the heartiest thanks for the earnestness you have manifested in these studies and explorations and also for the kindness and deference you have shown me. However, I should be very thankful to you if you would tell me, in all frankness, whether there is anything wherein I did not give you all satisfaction that you wish and it is my desire to give you, as it is also the order of my superior; it might have happened that, owing to my ignorance of the English language, or through inadvertence, I have not attended at once to some of your suggestions and observations.

Third-It is believed that the horticulturists of California have established the quarantine against our orange, taking as a pretext the danger of the plague, but, really, to avoid a competition which, as it is said, would be very prejudicial to them, because our oranges are better flavored and earlier than those of California. You have kindly given me some reasons which I would like you to indicate in your answer, because they would put an end to such suppositions.

According to the "Carpologia," of Barcena, the following are the dates at which the orange crop is produced:

Place.

Date of Ripening.

Value, Mexican.

Atotonilco el Alto. Tovember to May .

$\$ 1,800$

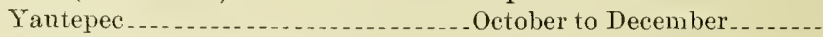

Montemorelos (Nuevo Leon) ........... October to February ........

Tancanhuitz (San Luis Potosi) ........ September to December ....

Rio Verde (San Luis Potosi) ........... October to March...........

Hermosillo

October to February ........

Guaymas (Sonora)

December to February .....

Comondu (Lower California).

October to December........

Santiago Huatusco (Cordova)

October and November.

36,000

50,000

12,630

15,000

7,000

6,600

2,500

Fourth-It is reported that the Sonora orange has been prohibited, if not in California, at least at some points on the Arizona railroad, for the commercial convenience of the horticulturists and railroad people of California.

However, such an assertion has been refuted by information sent to the sub-secretary of Fomento, Hon. Andres Aldasoro, by Mr. S. Camacho, as well as by the official reports from the Sonora Government. Even in 1897 Dr. L. O. Howard wrote in the Yearbook of the Department of Agriculture at Washington that the Trypeta ludens does not exist in the Sonora orange.

On another part, the oranges proceeding from Mexican points have been rejected and denied admission. At least so says a circular published by the Department of Fomento, 
and, I believe, to be short, that all these difficulties arose from the fact that the worm was found in some shipments of oranges from Acapulco, which is an infested place, as are many others in the tierra caliente, but whose production is insignificant.

Fifth-Mr. Craw says that the traffic agents of the Southern Pacific Railroad have rejected some shipments of MLexican oranges, and that, in fact, no tariff has been established on oranges between Mexico and California in order not to cause any prejudice to that important fruit industry of California. "The cars used for the transportation of Mexican oranges to the Western States, as I have been told by the agents, are disinfected by steam as soon as they are nnloaded, in order to kill the worms or nymphs that they may contain. This was done also last year, in accordance with an order from the Commission of Horticulture." (Report on quarantine, May 15, 1901.)

I truly believe that much of all this is the result of the false or exaggerated reports given by the press and the inconsiderate and generally exaggerated information sent by the commercial and express agents who may have definite and certain ideas about commercial matters, but who do not know sufficiently the plague we speak of, or who accept without any proof the information given by the traders or the newspapers. It should be part of our duty to make the necessary correction.

Sixth-In order to duly prove the absence of the Trypeta ludens in certain parts of the Republic, I offer to forward you branches of orange trees in full fruit-bearing state, which could, if there is no inconvenience, be examined in the office of the Quarantine Officer in California, thus giving you the assurance that the fruit has not been selected. Those remittals would be made regularly throngh the Department of Fomento.

I consider as very important that this question should be settled, because not even two years of contiuuous traveling at heavy expense would enable us to visit all the orange-producing regions of the Mexican Republic, as they extend from Sonora to Yucatan. It might be objected that we have visited the orchards during the month of March when the orange trees do not bear any fruit, and therefore that our reports can not give any security about the non-existence of the plague, which might be latent.

As the time would pass away, after three or four years, it might be argned that our explorations and proofs were already old and that the plague might have invaded new territory where heretofore it had been unknown. The experience acquired in that kind of work clearly shows that nothing good and definite can be obtained unless it be through constancy and a certain degree of tenacity which will lead sooner or later to a result that may challenge any attack.

Again thanking you sincerely, I remain,

Respectfully yours,

(Signed:) A. L. HERRERA.

P. S.-I herewith send you a copy of the letter lately addressed to Mr. Aldasoro and referring to the prohibition on the orange from California.

Mexico City, February 3, 1905.

Hon. Andres Aldasoro, Sub-Secretary of Fomento, Mexico City:

Dear Sir and Friend: Confirming the contents of my letter of January 28th last, I have the honor to communicate to you the information which, on the $3 d$ of the present month, Mr. J. A. Nougle, assistant general manager of the Sonora railroad, sent me in answer to my letter of January 28th.

"I hereby acknowledge the receipt of your favor of January 28th, wherein you communicated to me the letter sent to you by the Honorable Sub-Secretary of Fomento, about the law promulgated by the Department of Horticulture of California and the damage that may have been caused to our company by the same, prohibiting the importation of the Mexican orange into California.

"You may assure that honorable functionary that the mentioned liaw has caused no prejudice to us, because up to the present day nothing has been found to be saicl against the splendid Sonora orange, either in California or elsewhere.

"The only misfortune suffered by the growers and exporters of oranges in the State, and consequently by us, is that since the promulgation of the so-called Dingley Law, in force since July 24,1897 , the exportation of the orange to the United States has become materially prohibited, as the tariff of said law exacts 75 cents gold. 
"In order to give you a practical idea of what is going on, I send you the following comparative statistics:

$\begin{array}{ccc}\begin{array}{c}\text { Crops. } \\ 1899-1900\end{array} & \begin{array}{c}\text { Actual Exportation, } \\ \text { Carloads. }\end{array} & \begin{array}{c}\text { Possible Exportation, } \\ \text { Carloads. } \\ \text { About } 500\end{array} \\ 1900-1901 & 600 \\ 1901-1902 & 219 & 700 \\ 1902-1903 & & 800 \\ 1903-1904 & & 900 \\ 1904-1905 \text { (to date) } & & 1,000\end{array}$

"The mentioned exportation was shipped in a majority of cases to Canada; a small part went to Canauea via Nogales and Naco; another small part to the State of Chihuahua via Ciudad Juarez, and some more to the United States. It is proved that only 20 of the carloads of this year went to the United States, and I do not think the whole export of this year to that country will be above 26 carloads. As it seems that there is no remedy for the evil that afflicts us, some owners of magnificent orchards in Guaymas and Hermosillo are thinking of rooting out the numberless and beautiful orange trees which they planted about the time of the opening of this railroad in 1882 , because in both places oranges are sold at 25 cents a hundred and there are but very few purchasers.

"It must not be forgotten that the lumber and nails needed for the packing boxes, as well as the paper to wrap the oranges in, all come from the United States.

"I have wearied you with all these data in order to inform you of the situation and also to beg you to do all you can, conveniently, so that in some way or other a remedy may be brought for the serious prejudice suffered by the growers of such an excellent fruit and at the same time by this transportation line."

This I beg to submit to your superior knowledge as an answer to your favor of the 3 d inst.

Yours very respectfully,

(Signed:) S. CAMACHO.

Answer.

Mexico City, April 1, 1905.

Sr. Prof. A. L. Herrera, Commission of Parasitologia, Mexico, D. F.:

DEAR SIR: I beg to acknowledge the receipt of your communication of March 25th, which I have perused carefully, and, taking up your questions in their order, would respectfully reply as follows:

First-As oranges are grown to a greater or less extent over the greater part of Mexico, it will be impossible, in the limited time at my disposal, to visit all the places in the Mexican Republic where the orange is grown. It is my desire, however, to visit other of the more important orange sections than those already seen, especially those in the tierra caliente, and the habitat of the Trypeta ludens. It is my desire, as it is to the interest of both countries concerned, to give this matter the fullest possible investigation, in order that we may arrive at the actual truth in regard to the prevalence of the Trypeta ludens in Mexico, its extent, destructiveness, etc. In this matter I am certain, from the valuable aid which you have rendered me in the past, that I shall have your hearty coöperation. In furtherance of this work, I desire to visit, in the State of Vera Cruz, Cordova, Jalapa, and Vera Cruz; in the State of Jalisco, Guadalajara and La Barca. In the completion of my work, I desire to visit all points in the State of Tamaulipas and the vicinity of Tampico.

Second-I am much gratified to have been asked this question, as it gives me an opportunity to acknowledge the valuable assistance which I have received from you. Nothing has been left undone on your part or that of your assistants to give me the fullest opportunity for a thorough investigation. Every request which $I$ have made along these lines has been granted, and very many of my requirements have been anticipated. I have found in you a willing and able collaborator, and I owe the greater part of the knowledge I have obtained concerning the 1 rypeta ludens in Mexico to your valuable assistance, without which my efforts would have been surrounded with almost insurmountable difficulties. I will further add, that I am convinced that it is your 
desire, as it is also the desire of the Department of Fomento, which you represent, to have the entire truth regarding this pest made public, and to this end you have left no avenue closed which would lead me to the desired information.

Third-The belief that the horticulturists of California have placed an embargo on Mexican oranges, using the pest as an excuse, is an error. I assure you that nothing was ever farther from the policy of the State and the Department which I represent.

Oranges in small lots were occasionally brought to San Francisco, and so long as they were free from pests, were passed by our horticultural quarantine officer. On one occasion a shipment of several boxes from Acapulco was found to be badly infested with worms. This shipment was condemned. Other shipwents were found infested, and reports were made to our office of the pest being found in different parts of Mexico, especially along the line of the Mexican Central Railroad. It was these facts, and the dread of the introduction of this pest into our orange orchards, which led to the promulgation of the decree prohibiting the importation of Mexican oranges into the State of California. From what I have been able to learn during my researches here, I incline to the belief that the infested fruit reported along the line of the Mexican Central and in northern Mexico, was not grown in the sections where it was reported, but found its way from infested portions of the tierra caliente.

In regard to the statement that Mexican oranges are earlier than those of California, I can only say that our orange season is contimuous and that there is no month in the year in which shipments of this fruit are not made. Fruit ripens at different seasons in different parts of the State, and there are several varieties, as the Navel, Mediter. ranean Sweet, Valencia Late, etc., the ripening seasons of which so overlap that there is no break, in any part of the year, in the Califormia orange season.

When you consider that the California orange crop now reaches the important figure of 30,000 carloads annually, that it is one of the most important of our California industries, that in it are invested millions of dollars of capital, and that upon it thousands of our people depend for their bomes and their lives, you will nnderstand why we are so cautious about the introduction of any threatening danger; and if, through any inadvertence on our part, there should be admitted a pest which shonld damage even ten per cent of the crop, it would entail inestimable losses upon our people and our State. You will understand from this that it is the dread of an unknown evil, and not the fear of competition with Mexican growers, which has led us to place this embargo upon the Mexican orange.

Fourth-There is no embargo upon the importation of Mexican oranges into the United States, outside of California. California is the most important orange-growing State in the Union, and, ontside of Florida, is practically the only one in which the fruit is grown in commercial quantities, so that there is no reason why the Mexican fruit should not be admitted to all other points.

I think that, as stated in the communication of Sr. S. Camacho, a copy of which you have kindly furnished me, the present high tariff imposed by the United States Government on foreign oranges has more directly affected Mexican shippers than has the action of California. This, however, is a matter for the consideration of the United States Congress and one outside of my line.

Personally I may say that, with the present methods of growing, handling, packing, and shipping oranges in rogue in Mexico, were the American import duty entirely removed there would be no possibility of the Mexican orange competing in the open market with that of California, so long as California could produce enough to supply the demand.

Fifth-The statements made in this section are correct. Fearing the possibility of introducing the Trypeta ludens into the California orchards, the State Board of Horticulture prohibited the importation of the Mexican orange into the State, and the railroads running into it have refused to make a tariff on this fruit. Under the direction of Mr. Craw, all cars used for transportation of Mexican oranges are disinfected by steam before they can be used in the California trade.

The orange-growers of California may have been unduly alarmed concerning the situation here, and it is the object of my present mission to ascertain all the truth and remove, as far as possible, such fears, if they are unfounded. This I shall do in a full report; which will be published at as early a date as possible after my return. 
Sixth-I appreciate your very kind offer to forward to our quarantine department branches of fruiting orange trees, at different seasons, in order to convince us of the smallness of the danger. This is wholly unnecessary and would give you unneeded trouble. My observations and inquiries while in Mexico, aided as I have been by your valuable assistance, have given me the fullest possible information in this matter, and, while thanking you for the offer, I must decline putting yon to so much additional and unnecessary trouble.

In conclusion, I will state that I am convinced that the Department of Fomento, through the Commission of Parasitologia, and under your direction, has performed very intelligent and very thorough work, looking to the extermination of the Trypeta. ludens pest in those sections where it is known to exist; that it is the desire of your department, equally with the California Commission of Horticulture, to prevent this pest from being introduced into the United States, and that you are willing to coöperate with us in every way to this end. I believe, too, that our investigations will result in removing certain misunderstandings that have existed on the part of California growers as to the wide extent and destructiveness of the Trypeta ludens in Mexico, and, on the part of the Mexican growers, as to the fear of competition, by Californians, from Mexican fruit. I assure you that it has been from no feeling of jealousy regarding the Mexican fruit that California has acted, but wholly from a desire to protect one of our greatest industries from what appeared to us a serious and threatening danger.

Again thanking you for your valuable assistance and many courtesies which I have received, I have the honor to remain,

Yours very sincerely,

(Signed:) JOHN ISAAC, Special Commissioner.

\section{Communication from the Secretary of the Department of Fomento.}

Mexico City, April 8, 1905.

To JoHx IsAac, EsQ.,

Special Commissioner of the State Commission of Horticulture of California:

Informed of the zeal you have displayed in the course of your investigations relative to the habitat of the Morelos worm (Trypeta ludens), its actual importance, the means. used in fighting it, and the possibility of destroying the same; aware also of the tenor of the preliminary report which you address to Hon. Ellwood Cooper, President of the Board of Horticulture of California, giving him information upon the true importance of the plagne, the Secretary of this Department thanks you for your work, trusting you will kindly transmit the expression of his gratitude to Hon. Ellwood Cooper and the Governor of California, with the understanding that this manifestation takes place through the official chamnel.

(Signed:) ESCONTRIA, Secretary of the Department of Fomento.

\section{Answer.}

To the Honorable Secretary of the Department of Fomento-Present:

HoNorable SIR: I have the honor to acknowledge the receipt of your communication No. 7981, wherein you ask me to transmit your thanks to the Hon. Ellwood Cooper and to the Governor of California, for the interest they have manifested in the study of the Mexican orange and the Trypeta luelens.

In answer, I have the honor to inform you that I have great satisfaction and pleasure in forwarding copies of your communication to Hon. Ellwood Cooper and the Governor of California. For my own part, I give you my heartiest thanks for the attention of which I have been the object and the facilities that have been furnished me for my investigations.

With the sentiments of the truest consideration, I remain,

Very respectfully yours,

JOHN ISAAC. 

